\title{
The Role of HVAC Design and Windows on the Indoor Airflow Pattern and ACH
}

\author{
Behrouz Pirouz $^{1, *(\mathbb{D})}$, Stefania Anna Palermo ${ }^{2} \mathbb{D}$, Seyed Navid Naghib ${ }^{1}$ (D), Domenico Mazzeo ${ }^{1}$ (D), \\ Michele Turco $^{2}$ (D) and Patrizia Piro ${ }^{2}$ \\ 1 Department of Mechanical, Energy and Management Engineering, University of Calabria, \\ 87036 Rende, CS, Italy; navid.naghib@gmail.com (S.N.N.); domenico.mazzeo@unical.it (D.M.) \\ 2 Department of Civil Engineering, University of Calabria, 87036 Rende, CS, Italy; \\ stefania.palermo@unical.it (S.A.P.); michele.turco@unical.it (M.T.); patrizia.piro@unical.it (P.P.) \\ * Correspondence: behrouz.pirouz@unical.it; Tel.: +39-0984-496542
}

Citation: Pirouz, B.; Palermo, S.A.; Naghib, S.N.; Mazzeo, D.; Turco, M.; Piro, P. The Role of HVAC Design and Windows on the Indoor Airflow Pattern and ACH. Sustainability 2021, 13, 7931. https://doi.org/10.3390/ su13147931

Academic Editors: Giouli Mihalakakou and Chi-Ming Lai

Received: 22 April 2021

Accepted: 14 July 2021

Published: 15 July 2021

Publisher's Note: MDPI stays neutral with regard to jurisdictional claims in published maps and institutional affiliations.

Copyright: (c) 2021 by the authors. Licensee MDPI, Basel, Switzerland. This article is an open access article distributed under the terms and conditions of the Creative Commons Attribution (CC BY) license (https:/ / creativecommons.org/licenses/by/ $4.0 /)$.

\begin{abstract}
The purpose of heating, ventilation, and air conditioning (HVAC) systems are to create optimum thermal comfort and appropriate indoor air quality (IAQ) for occupants. Air ventilation systems can significantly affect the health risk in indoor environments, especially those by contaminated aerosols. Therefore, the main goal of the study is to analyze the indoor airflow patterns in the heating, ventilation, and air conditioning (HVAC) systems and the impact of outlets/windows. The other goal of this study is to simulate the trajectory of the aerosols from a human sneeze, investigate the impact of opening windows on the number of air changes per hour $(\mathrm{ACH})$ and exhibit the role of dead zones with poor ventilation. The final goal is to show the application of computational fluid dynamics (CFD) simulation in improving the HVAC design, such as outlet locations or airflow rate, in addition to the placement of occupants. In this regard, an extensive literature review has been combined with the CFD method to analyze the indoor airflow patterns, $\mathrm{ACH}$, and the role of windows. The airflow pattern analysis shows the critical impact of inflow/outflow and windows. The results show that the CFD model simulation could exhibit optimal placement and safer locations for the occupants to decrease the health risk. The results of the discrete phase simulation determined that the actual $\mathrm{ACH}$ could be different from the theoretical $\mathrm{ACH}$ as the short circuit and dead zones affect the $\mathrm{ACH}$.
\end{abstract}

Keywords: indoor environment; airflow; HVAC; ACH; UV light; CFD; COVID-19; IAQ

\section{Introduction}

Optimal thermal comfort and appropriate IAQ are vital for occupants. The purpose of HVAC systems is to create thermal comfort and optimal air quality with minimum health risk for occupants [1]. Major IAQ parameters include $\mathrm{CO}, \mathrm{CO}_{2}, \mathrm{NH}_{3}, \mathrm{O}_{3}, \mathrm{NO}_{2}$, aldehydes, VOCs (volatile organic compounds), and atmospheric aerosol particles such as PM (particulate matter) [2,3], in addition to biological pollutants such as fungi, bacteria, and viruses $[4,5]$. The analysis determined that the standard ventilation rate for residential buildings in many European countries is about 0.35-1 ACH [6]. From a health perspective, in another study, the monitoring of $\mathrm{CO}_{2}, \mathrm{~T}$, and $\mathrm{RH}$ (relative humidity) is suggested for improving the indoor environment [7]. High indoor RH could increase health risks and HDM infestations (house dust mites), as well as lead to the growth of MVOCs (Microbial volatile organic compounds) in indoor air [8,9]. The measurements of indoor air quality in 32 homes in China wherein occupants were reported to have sick building syndrome (SBS) reveals that the sickness happened while the ventilation rates were among 0.35 and $0.78 \mathrm{ACH}[10]$. The indoor $\mathrm{CO}_{2}$ concentration in a room is mainly based on human activities and is a simple parameter for measuring the actual IAQ, while the recent studies focus are reducing electricity and energy costs [11]. 
Wallace et al. analyzed the effect of windows, wind, temperature, and fans on the air change rates. The analysis determined that the effect of opening windows or fan on $\mathrm{ACH}$ were several times more than temperature change. The impact of wind speed and direction on ACH was very little [12]. The low ventilation and ACH could increase the concentration of indoor pollutants, and the main impact of on occupants are as follow $[13,14]$ :

- $\quad$ Decrease of comfort level;

- Increase of health risk (i.e., asthma, inflammation, infections, allergy);

- $\quad$ Sick building syndrome (SBS);

- Decrease of productivity.

Dimitroulopoulou analyzed house ventilation in different countries in Europe and examined the compatibility of standards/regulations. The results of the analysis determined the impact of adequate ventilation on human health. In practice and based on the measurements of several case studies, the ventilation of the houses is often poor and less than $0.5 \mathrm{ACH}[6]$.

\subsection{The COVID-19 Outbreak and the Role of HVAC on the Indoor Contamination Load}

The COVID-19 outbreak was identified in early 2020 and shortly affected 213 countries and territories worldwide with more than 105 million confirmed cases and 2.3 million deaths in about one year $[15,16]$. The outbreak of the new pandemic has been one of the most important issues in many countries as it can negatively affect the sustainable development elements [17-19] of nearly all 17 goals of the 2030 Agenda by the UN (United Nations) [20-22].

The selection of an HVAC system depends on the building type, regulations, standards, and climate type [23-25]. The analysis shows that using HVAC systems for comfort air temperature could prevent the growth rate of bacteria, but in the case of viruses, it depends on the type of air conditioner [26,27]. In addition, the analysis showed that the transmission of contaminated droplets could be accelerated by air conditioner airflow [28]. The analysis determined the relationship between temperature and the positive cases of COVID-19 [29-32].

The air-conditioning, ventilating, and heating systems may decrease or accelerate the spread of infectious diseases such as influenza [33]. Generally, air conditioner systems are not designed to filter small particles such as COVID-19. Thus the closed systems (recirculating) could increase the infection risk [34,35]. There are approved correlations among the infection rates and the indoor parameters, including humidity percentage, airflow direction, periodic cleaning of the ventilation systems, type of used air filter, and $\mathrm{ACH}[36]$.

Shajahan et al. investigated the impact of the air conditioning, ventilation system, and indoor environment of a hospital on controls of infection rates. The results determined the impact of the built environment, ventilation strategies, and vents/exhaust filtration systems on the contamination load [37]. Lu et al. [28] analyzed the impact of air conditioning in restaurants on the spread of COVID-19 infections. Their investigations determined that ten people of three different families obtain a COVID-19 infection in a restaurant in China from one infected person located at a neighboring table with a distance of more than one meter. The analysis approved the role of airflow by AC systems as none of the staff were infected, the air conditioner filter tests were negative, and there were no positive cases in other tables, just in the tables in the direction of air conditioner's airflow.

The analysis determined that mixing ventilation systems could better decrease contamination load [37]. The important parameters in the case of ventilation could be the location of the ventilation $[38,39]$ and the position and distance of the persons (employee, students, customers, etc.) that all affect the concentration of pollutants [40]. Another critical factor in the ventilation systems is the airflow direction that could prompt droplet transmission [28]. The standard protocols of infection prevention and control (IPC) for potential airborne transmission of the virus suggested by the National Quarantine Unit of the USA mainly 
include negative-pressure rooms with more than $12 \mathrm{ACH}$ and the use of air-purifying respirators [41].

\subsection{The Transmission Mechanism of Contaminated Aerosols by Airflow}

The spread of respiratory infections can be mainly through contaminated fluid particles by viruses such as droplets and aerosols [42]. The persistence of COVID-19 in aerosols could be up to several hours $[43,44]$. The infectious aerosols by SARS-CoV-2 could persist in the air for some hours, be trapped, and remain for several days on the surfaces depend on the material. The experimental analysis showed a reduction of the infectious titer after three hours from $10^{3.5}$ to $10^{2.7} \mathrm{TCID}_{50}$ (tissue-culture infectious dose) per liter of air. In addition, the half-lives of COVID-19 in aerosols were about 1.1 to $1.2 \mathrm{~h}$ with $95 \%$ reliable intervals of 0.64 to 2.64 [45].

The analysis determined that SARS-CoV-2 could spread in two mechanisms, including directly through droplets and person-to-person and indirectly through airborne transmission and contaminated objects. The analysis of two air samples in the Nebraska Biocontainment Unit (NBU), first near an infected patient's bed (receiving oxygen via nasal cannula) and second in a distance of $2 \mathrm{~m}$, showed that both were positive, and the air concentration in the first sample was higher than the second, 4.07 to 2.48 copies/L of air. Even the samples in the hallways outside the patients' room were positive, while the virus concentration was about 2.51 copies/L of air [46].

The previous studies showed that the main portion of mouth aerosol during different activities such as talking, breathing, and even coughing have a size less than $10 \mu \mathrm{m}$ in diameter, and the respirational diseases increase the number of aerosol particles with the same size [47]. This also means that the virus can be transferred in the environment through respiration aerosol by infected people, even in the absence of cough [48]. The respiratory virus transmission can be categorized based on the droplet size into two groups as follows [28,49,50]:

- $\quad$ Larger respiratory droplets (more than $5 \mu \mathrm{m}$ ): These droplets can remain in the air for a short time, and travel can spread short distances, generally less than $1 \mathrm{~m}$;

- Virus-laden, small, aerosolized droplets (less than $5 \mu \mathrm{m}$ ): These droplets can remain floating and travel more than $1 \mathrm{~m}$.

In general, the droplets more than $10 \mu \mathrm{m}$ are heavy and are suspended for a short time in the air. Thus, the impact of gravity is greater than that of the ventilation systems [51]. To decrease the risk of infection from these particles, a distance of 1 to $2 \mathrm{~m}$ could be more useful than ventilation [52]. However, some droplets or those with reduced diameters of 2.5 to $10 \mu \mathrm{m}$ due to the evaporation could change to the aerosols, significantly influence ventilation systems $[53,54]$.

\subsection{The Impact of Supplementary Approaches in Decreasing Indoor Contamination Load}

This section explains the role of air filters and UV lights as two supplementary approaches in decreasing contamination loads. Both approaches can be used to improve low $\mathrm{ACH}$, especially in the recirculation air conditioner systems.

\subsubsection{The Impact of Air Filtration Systems on Indoor Contamination Load}

The impact of filters such as High-Efficiency Particulate Air (HEPA) filtration systems studied by many researchers showed the advantages and disadvantages of each type of filter in reducing the contamination load. Sportelli et al. analyzed the impact of nanomaterial against the COVID-19 pandemic. They investigated the antimicrobial properties of nanomaterials in filter production. The results determined that the efficiency in decreasing virus spread [55].

Appropriate air filters may decrease the virus loads in the closed area that is very important in the COVID-19 pandemic, and the possibility of getting an infection from contaminated aerosols through the Personal Protective Equipment (PPE) will decrease [43]. The HEPA filters decrease the load of bacteria, which is very important for hospitals [56], 
and decrease airborne viruses and fungi [57]. The circulation ventilation systems by using HEPA filtration can reduce the droplet nuclei by 30 to $90 \%$ [51]. In addition, the implementation of some materials such as antibacterial and antiviral agents might increase HEPA filters' effectiveness [55].

Using HEPA filters alone might not effectively confront fungal spores since the filter materials are vulnerable to fungal degradation, especially in humid conditions [58,59]. This issue can occur in the filters inside the ducts for central and evaporative air conditioners, and the filter might be contaminated and become a source of microorganisms itself $[60,61]$. The nanocomposites such as polyurethane, $\mathrm{CuO}$, and bioactive nanoparticles can be used in air filters due to the practical antimicrobial impact $[62,63]$.

\subsubsection{The Impact of Ultraviolet Light (UW) on Contaminated Aerosols}

Grant and Giovannucci analyzed the impact of UV on the infection rate. Their results showed that the rate of the COVID-19 pandemic could be connected to the latitudes [64]. Bang et al. analyzed the sterilization role of upper-room ultraviolet germicidal irradiation (UR-UVGI) on respiration syndromes, including SARS and MERS. They modeled the airborne contaminants flow using CFD analysis and by the consideration of several scenarios. Their results show that the sterilization effect depends on the UV level. In addition, the locations of elements in the airflow are important, including the source of microorganisms, air supplies, exhausts, and the UVGI system, and the best situation for placing the UVGI system was found to be in the upper part of the ward entrance [65].

Required UV Dosage depends on the intensity of radiation, exposure time, the purpose of use. Ultraviolet light is a component of the electromagnetic spectrum situated in a region among visible light and X-Rays, from 100 to $400 \mathrm{~nm}$. The UV lights categorized based on the wavelengths as follow [66]:

- 100 to $200 \mathrm{~nm}$ : Far UV or vacuum UV;

- 200 to $280 \mathrm{~nm}$ : UVC (suitable for disinfection and sensing);

- 280 to $315 \mathrm{~nm}$ : UVB (suitable for curing, medical applications, and tanning);

- 315 to $400 \mathrm{~nm}$ : UVA (suitable for curing, lithography, printing, and medical applications).

The Centers for Disease Control and Prevention (CDC) recommended the use of UVGI (ultraviolet germicidal irradiation) as an effective method to reduce the spread of airborne microorganisms [67]. However, UVGI can be used as an adjunct method and cannot be replaced with HEPA filtration [68]. High levels of UVGI can be used inside the ventilation ducts to disinfect the air before recirculation and in the upper-room area [69] or rooms in the absence of people [70]. The effectiveness of UVGI with a sufficient time could be equal to 10-39 ACH [71]. Since the COVID-19 pandemic issue is new, there is no specific deactivation dosage by UVC yet. However, the dosage values to achieve $99.9 \%$ disinfection for similar viruses (SARS family) under controlled lab conditions are 10 to $20 \mathrm{~mJ} / \mathrm{cm}^{2}$ with direct UVC in a wavelength of $254 \mathrm{~nm}$. The same disinfection impact in office or classroom settings could be achieved in dosages between 1000 and $3000 \mathrm{~mJ} / \mathrm{cm}^{2}$ since all contaminated particles might not be in direct UVC light [72].

The negative health impact of low ventilation and $\mathrm{ACH}$ on occupants is obvious by reviewing the previous studies. The analysis determined that the $\mathrm{ACH}$ in many European countries is currently about 0.35-1 ACH [6] and in China, about 0.35-0.78 ACH [10]. Meanwhile the standard protocols for prevention of airborne transmission infections, which could be important during the COVID-19 pandemic, is more than $12 \mathrm{ACH}$ [41]. The different recommended ACH values in countries can also depend on the energy efficiency regulations, such as nearly zero energy buildings (NZEB).

The previous studies are mainly about optimal thermal comfort, NZEB, and decreasing energy consumption, resulting in less ACH. However, the optimal air quality with minimum health risk for occupants is also an important factor, which depends on the standard thresholds of $\mathrm{ACH}$, and the design elements counting as the first knowledge gap. Although some case study analyses investigated the HVAC systems and natural air 
ventilation, no study has analyzed the impact of windows on airflow and $\mathrm{ACH}$ while using HVAC systems. In fact, opening the windows while using HVAC means a waste of energy, but due to the COVID-19 pandemic, it is suggested by health care sectors.

Therefore, the study's main goal is to analyze the impact of windows on the indoor airflow patterns and trajectory of aerosols in the HVAC systems by using CFD simulation. Another goal is to investigate the impact of windows on full ACH in comparison with theoretical ACH due to the impact of dead zones with low airflow speed. The final goal of the study is to show the application of CFD simulation in improving the HVAC design, such as outlet locations and airflow rate in addition to the placement of occupants. Although the transmission of the virus and medical investigation are out of the study scope, the results could decrease the health risk in the indoor environments in addition to improving the monitoring and IAQ systems.

\section{Materials and Methods}

Many factors affect indoor air quality, from flow rate to environmental parameters (i.e., temperature, humidity, $\mathrm{CO}_{2}$, etc.) [73,74]. In addition, the literature-review-based analysis determined some techniques for decreasing the health risk, such as the use of HEPA filters and UV light for decreasing the contamination load and sterilizing the indoor environment [75]. In the case of the COVID-19 pandemic, there are several cases in which healthcare workers obtain an infection even by using Personal Protective Equipment (PPE) and barrier precautions due to the high contamination load [76].

To analyze complex problems, one can use mathematical, numerical, or statistical methods [77-80], and in this study, the numerical method using a Computational Fluid Dynamic (CFD) solver has been applied. In this study, an extensive literature review analysis combined with CFD simulation for analysis of indoor airflow pattern, $\mathrm{ACH}$, and the impact of opening windows is conducted. The analysis process by using CFD simulation is according to the flowchart in Figure 1.

First, the main factors involving the HVAC systems have been investigated, and then, according to the evaluation of several case studies, the boundary conditions for model setup have been determined. The average values based on several case studies make the outcomes more reliable as the results are not limited to any specific case. Second, the geometry of the models has been defined, and validations of the models have been done according to the selected studies. Third, the validated models have been used to analyze airflow pattern, the trajectory of aerosols, and the impact of windows on $\mathrm{ACH}$ while using HVAC system in a typical office and classroom. To study the full $\mathrm{ACH}$ and the impact of the windows, a discrete phase model has been applied. The aerosols transport by consideration of the average size for respiration aerosols in a cough or sneeze has been simulated. Finally, according to the model results and extensive literature review, some suggestions to improve the indoor $\mathrm{ACH}$ have been presented.

The modeling results allow us to compare the theoretical $\mathrm{ACH}$ based on the inflow rate and dimensions and the full $\mathrm{ACH}$ based on the simulation considering dead zones with low airflow. Moreover, the simulation would make it possible to check the impacts of outlets location in full $\mathrm{ACH}$, minimizing the dead zones (area with low airflow speed). 


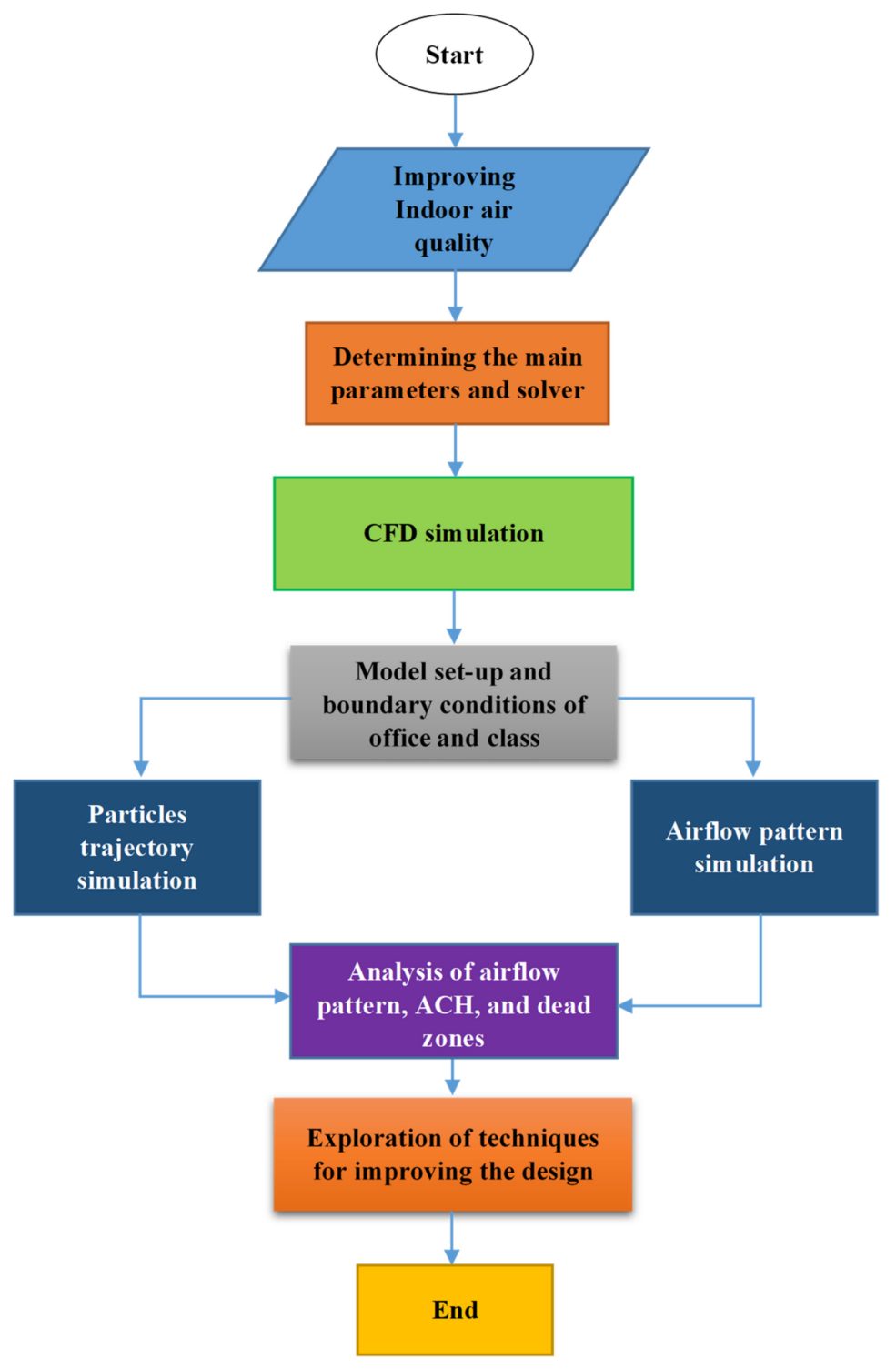

Figure 1. Analysis flowchart.

\section{Model Development}

3.1. Research Hypotheses and Assumptions

The hypotheses and assumptions in the study are as follows:

- $\quad$ Since the airflow pattern and $\mathrm{ACH}$ are among the analysis purposes, the simulations have been done in steady thermal conditions. Therefore, the steady-state condition with the inflow temperature of $25^{\circ} \mathrm{C}$ has been used for simulation;

- The central air conditioner systems in the rooms are fully fresh air and without recirculation. In addition, the impact of natural ventilation is not considered in this study;

- To calculate the full ACH, the worst condition has been selected for the locations of the possible infection source (aerosol injection). Therefore, the class center, a location with the longest distances from the outlets and windows, has been selected. The remaining time of the particles in any other locations of the class will be less. In the office case, two different locations have been selected for analysis of the aerosol movement.

- The simulation of the cases with open and closed windows can show the impact of changing outflow on the airflow pattern and ACH. Therefore, the number of windows cannot change the main result; 
- The outside wind could cause some turbulence and affect the airflow pattern. However, it has been neglected in the current study.

- The initial validation of the model with previous case studies could be acceptable for analysis of the rooms with bigger sizes and more objects;

\subsection{Main Governing Equations}

The equations governing fluid motion in ANSYS are all derived from three basic physics conservation laws, including the Navier-Stokes equation (momentum conservation), continuity equation (mass conservation), and energy equations (energy conservation), Equations (1)-(3) [81,82].

Momentum:

$$
\begin{aligned}
& \partial(\rho \mathrm{u}) / \partial \mathrm{t}+\nabla \cdot(\rho \mathrm{u} \vec{V})=-\partial p / \partial \mathrm{x}+\partial \tau \mathrm{xx} / \partial \mathrm{x}+\partial \tau \mathrm{yx} / \partial \mathrm{y}+\partial \tau \mathrm{zx} / \partial \mathrm{z}+\rho \mathrm{fx} \\
& \partial(\rho \mathrm{v}) / \partial \mathrm{t}+\nabla \cdot(\rho \mathrm{v} \vec{V})=-\partial p / \partial \mathrm{y}+\partial \tau \mathrm{xy} / \partial \mathrm{x}+\partial \tau \mathrm{yy} / \partial \mathrm{y}+\partial \tau \mathrm{zy} / \partial \mathrm{z}+\rho \mathrm{fy} \\
& \partial(\rho \mathrm{w}) / \partial \mathrm{t}+\nabla \cdot(\rho \mathrm{w} \vec{V})=-\partial p / \partial \mathrm{z}+\partial \tau \mathrm{xz} / \partial \mathrm{x}+\partial \tau \mathrm{yz} / \partial \mathrm{y}+\partial \tau \mathrm{zz} / \partial \mathrm{z}+\rho \mathrm{fz}
\end{aligned}
$$

Continuity:

$$
\frac{\partial \rho}{\partial t}+\nabla \cdot(\vec{V})=0
$$

where $p$ is pressure and $\rho$ is the fluid density.

Energy equation:

$$
\frac{\partial}{\partial t}(\rho E)+\nabla \cdot(\vec{v}(\rho E+p))=-\nabla \cdot\left(\sum_{j} H_{j} J_{j}\right)+S_{h}
$$

To track the movement of particles within another fluid, the discrete model can be applied. In this method, the force balance for particle cloud needs to be calculated, which means the particle inertia with the acting forces. To predict the particle (aerosol) trajectory, the motion equations can be used, as in Equations 4 and 5 [83]:

$$
\begin{gathered}
\frac{d u_{p}}{d t}=\frac{g_{x}\left(\rho_{p}+\rho\right)}{\rho_{p}}+F_{D}\left(u-u_{p}\right)+F_{x} \\
F_{x}=\frac{1}{2} \frac{\rho}{\rho_{p}} \frac{d}{d t}\left(u-u_{p}\right)
\end{gathered}
$$

where: $u$-fluid phase velocity, $u_{p}$ —particle velocity, $\rho$-fluid density, $\rho_{p}$-particle density, $F_{D}\left(u-u_{p}\right)$-drag force per unit particle mass, and $F_{x}$-additional forces.

\subsection{Model Design and Boundary Conditions}

The boundary conditions in several case studies have been evaluated for developing the models, and the average values have been used. The simulation has been done in the steady-state condition, with an airflow temperature of $25^{\circ} \mathrm{C}$. Table 1 shows the boundary condition in five previous case studies and the boundary condition for the selected typical office and class. The dimensions are according to the typical classes and offices in the University of Calabria, Italy, and the airflow speed and airflow rate are the average values of the five selected case studies. 
Table 1. Boundary conditions for selected case studies.

\begin{tabular}{|c|c|c|c|c|c|c|}
\hline \multirow{2}{*}{ Case Study } & \multicolumn{3}{|c|}{ Size $[\mathrm{m}]$} & \multirow{2}{*}{$\begin{array}{c}\text { Airflow Rate } \\
{\left[\mathrm{m}^{3} / \mathrm{s}\right]}\end{array}$} & \multirow{2}{*}{$\begin{array}{l}\text { Airflow Speed } \\
{[\mathrm{m} / \mathrm{s}]}\end{array}$} & \multirow{2}{*}{ Refs. } \\
\hline & Length & Width & Height & & & \\
\hline Yongson et al. (2017) & 3.7 & 2.7 & 3 & - & 5 & {$[84]$} \\
\hline ANSI / ASHRAE (2007) & - & - & - & - & 0.8 & [85] \\
\hline Asmi et al. (2014) & - & - & - & $0.08-1.53$ & 1.19 & {$[86]$} \\
\hline Fulpagare and Agrawal (2013) & 14 & 13 & 3.6 & - & $0.7-1.4$ & [87] \\
\hline Yu et al. (2020) & - & - & - & - & $0.4-2.4$ & [88] \\
\hline Typical Office & 12 & 9 & 3.5 & 0.6 & 1.5 & \multirow[b]{2}{*}{1} \\
\hline Typical Class & 12 & 9 & 3.5 & 0.6 & 1.5 & \\
\hline
\end{tabular}

${ }^{1}$ The dimension and airflow speed for a typical class and office.

The properties and boundary conditions of the respiratory particles for simulation of a discrete phase model are presented in Table 2. As can be seen in the table, the diameter of human respirational aerosol is between 0 to $100 \mu \mathrm{m}$, on average $5 \mu \mathrm{m}$. The speed of respiratory aerosol is between 0.12 and $1 \mathrm{~m} / \mathrm{s}$, and for a cough and sneeze, from 4.2 to $11.2 \mathrm{~m} / \mathrm{s}$, on average about $10 \mathrm{~m} / \mathrm{s}$. Therefore, in this study, the average dimension of the aerosols in one cough or sneeze is $5 \mu \mathrm{m}$ with a speed of $10 \mathrm{~m} / \mathrm{s}$ and a duration of $0.5 \mathrm{~s}$ has been selected for boundary conditions.

Table 2. Boundary conditions for respiratory particles.

\begin{tabular}{cccccc}
\hline Aerosols & $\begin{array}{c}\text { Particle } \\
\text { Diameter }[\mu \mathrm{m}]\end{array}$ & Injection Speed $[\mathbf{m} / \mathbf{s}]$ & $\begin{array}{c}\text { Mass Flow } \\
\text { Rate [mg/s] }\end{array}$ & $\begin{array}{c}\text { Injection } \\
\text { Duration [s] }\end{array}$ & $\begin{array}{c}\text { Refs. } \\
\text { steady }\end{array}$ \\
\hline Yang et al. (2020) & 10,50 & 0.12 (respiration) & - & 0.5 & {$[89]$} \\
Yang et al. (2018) & $\approx 10$ & 11.2 (sneeze) & - & 0.5 & {$[90]$} \\
Yan et al. (2020) & $0-100$ & $0.3-1$ (respiration) & - & $51]$ & {$[92]$} \\
Zhang et al. (2019) & 5 & $4.2-10$ (caugh and sneez) & 5 & 5 & 0.5 \\
\hline Selected size of particles & 5 & 10 & &
\end{tabular}

\subsection{CFD Model Set Up}

The model setup (geometry and mesh) details in the selected case studies are shown in Figures 2-6, with the locations of inlets, outlets/windows, and aerosol injection source location for analysis of aerosol trajectory in the discrete model and calculation of $\mathrm{ACH}$. For decreasing the error and uncertainty in the mesh, the details of the models are simplified, particularly for the human bodies, as recommended in previous studies $[93,94]$. The turbulence method of $k-\varepsilon$ has been selected for the simulation since the performance was verified in similar case studies [95-99]. For decreasing the simulation error, the suggested methodologies in the previous studies have been considered for airflow pattern simulation [100], and for the discrete modeling, the recent studies on aerosol transmission have been considered [93,97,101,102].

The mesh sensitivity analysis is presented in Figure 7 and details of the final mesh are presented in Table 3. The skewness and orthogonal quality determine the final meshes are suitable for simulation.

The details of the CFD model setup in ANSYS software are presented in Table 4.

For verification, the developed models were validated based on the velocity profile of the measurement data in the previous studies by Ahn and Choi [97] and Zhang et al. [92]. Then, the simulations were completed for the selected boundary conditions in the current study. The validation results are shown in Figure 8. 


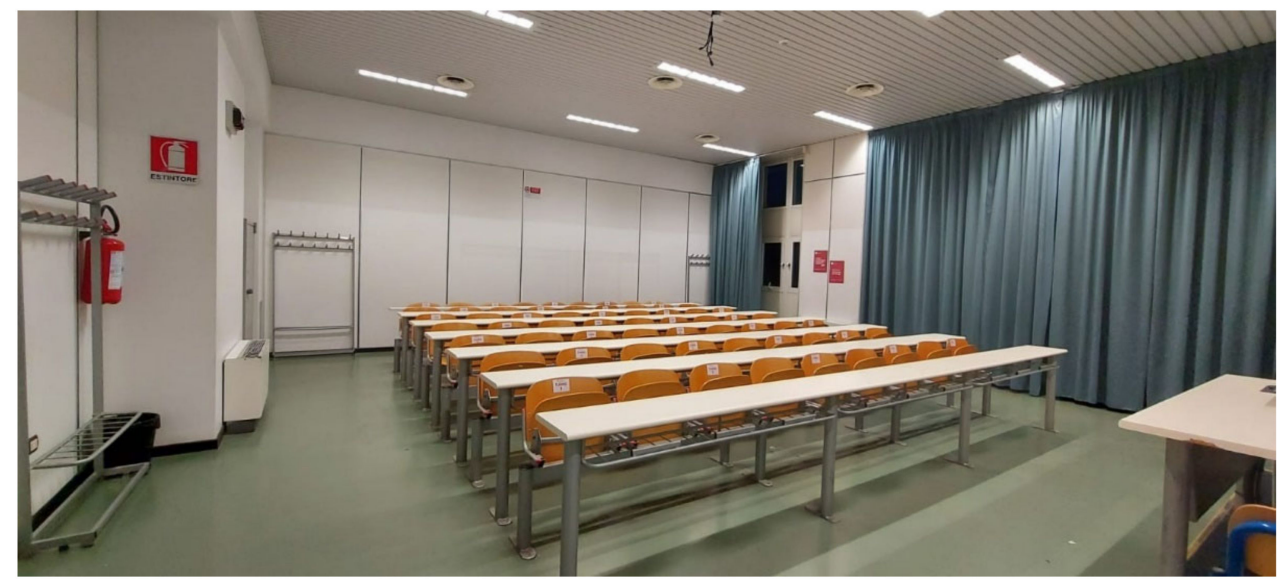

(a)

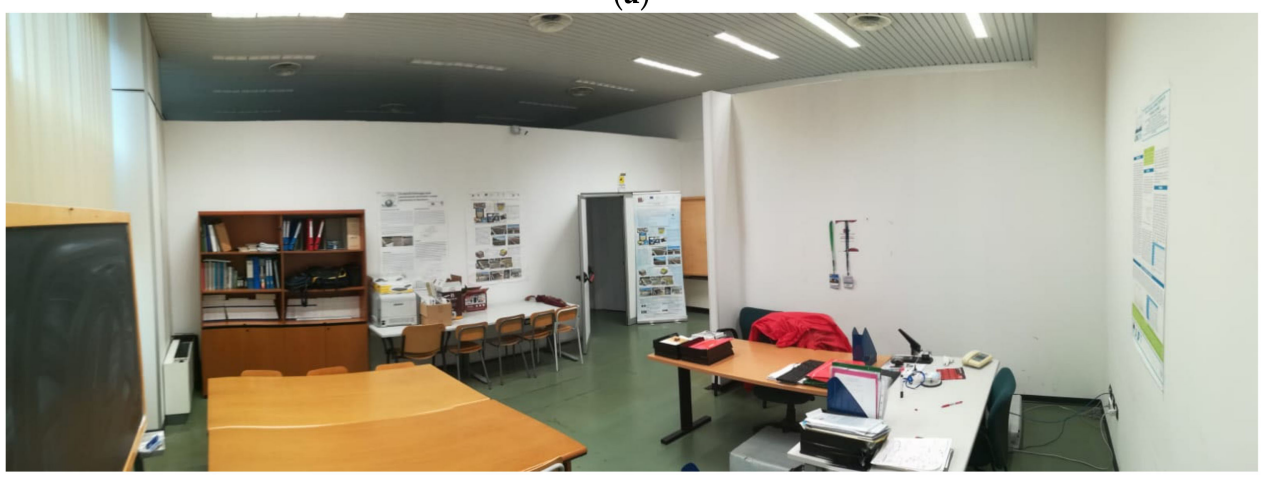

(b)

Figure 2. The images of (University of Calabria, Italy) (a) a typical class (b) a typical office with laboratory.
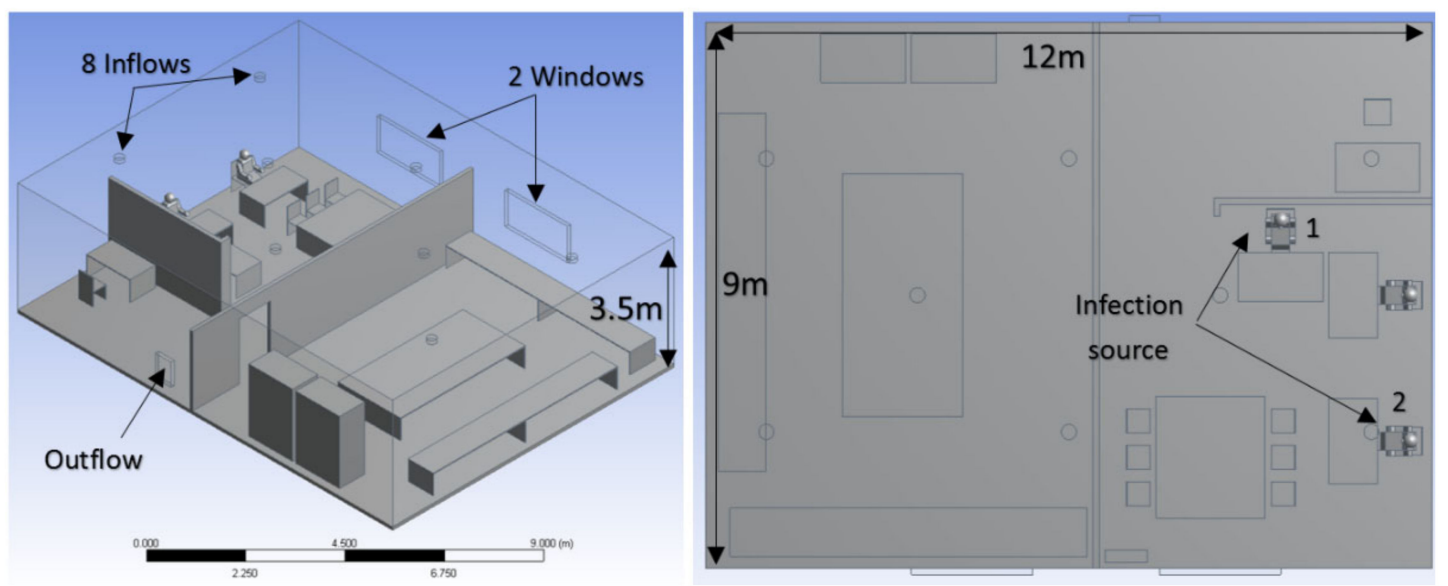

Figure 3. Model setup of the office with the location of components and employees. 


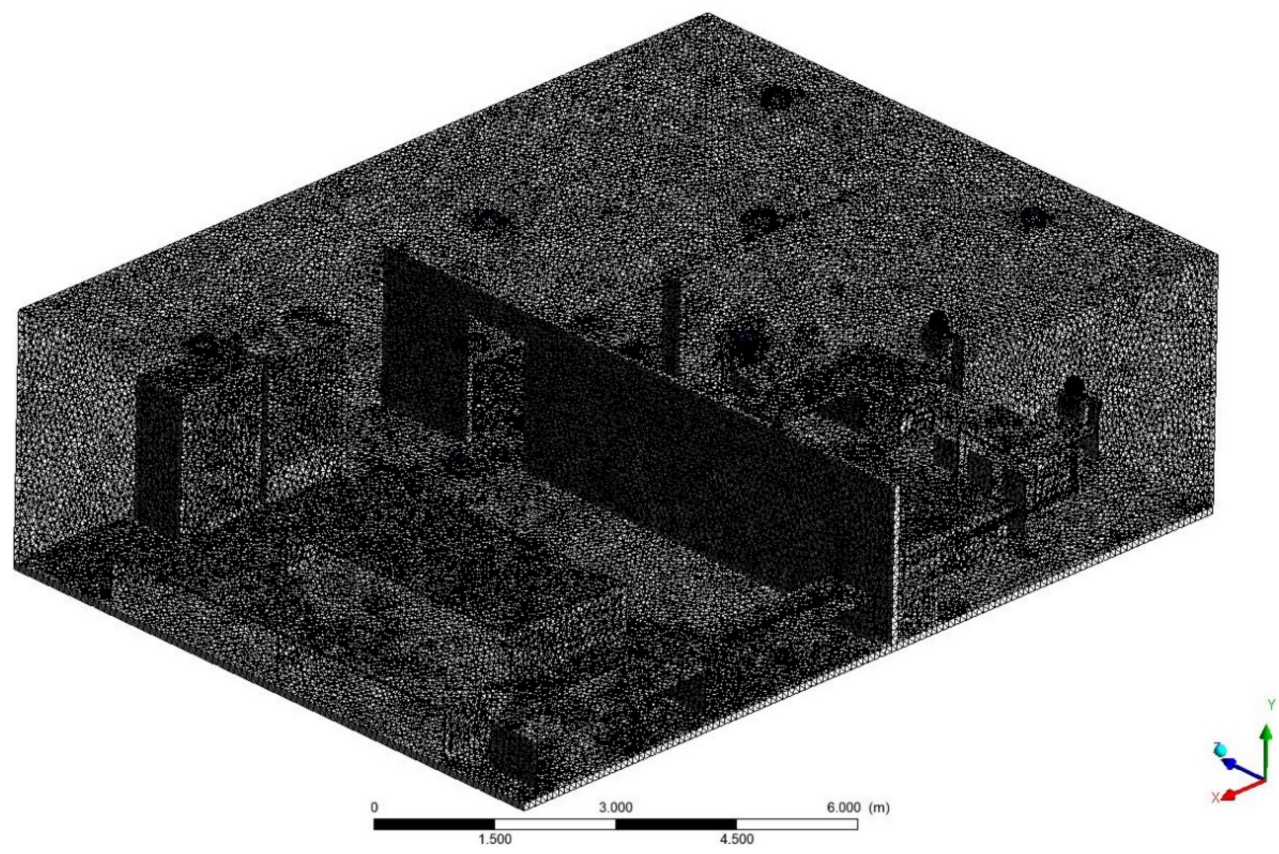

Figure 4. Mesh of the typical office model.

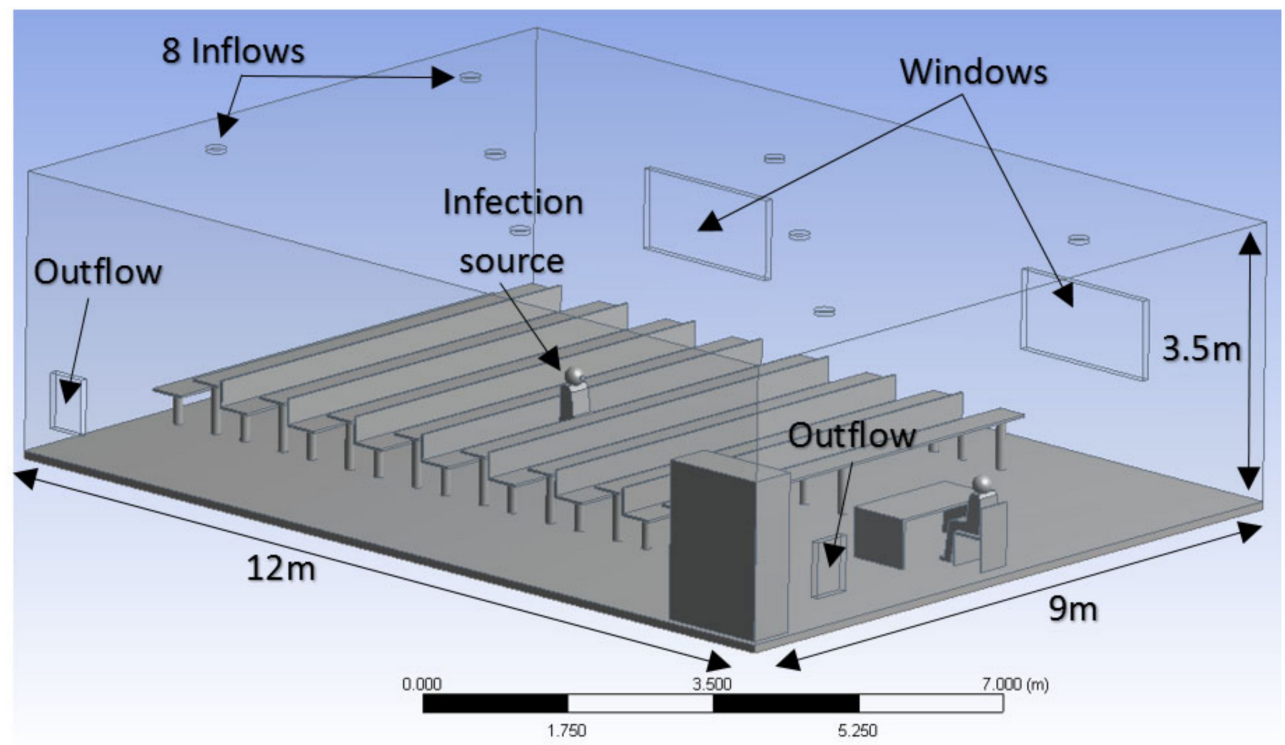

Figure 5. Computational model setup of a typical class with the location of components and student. 


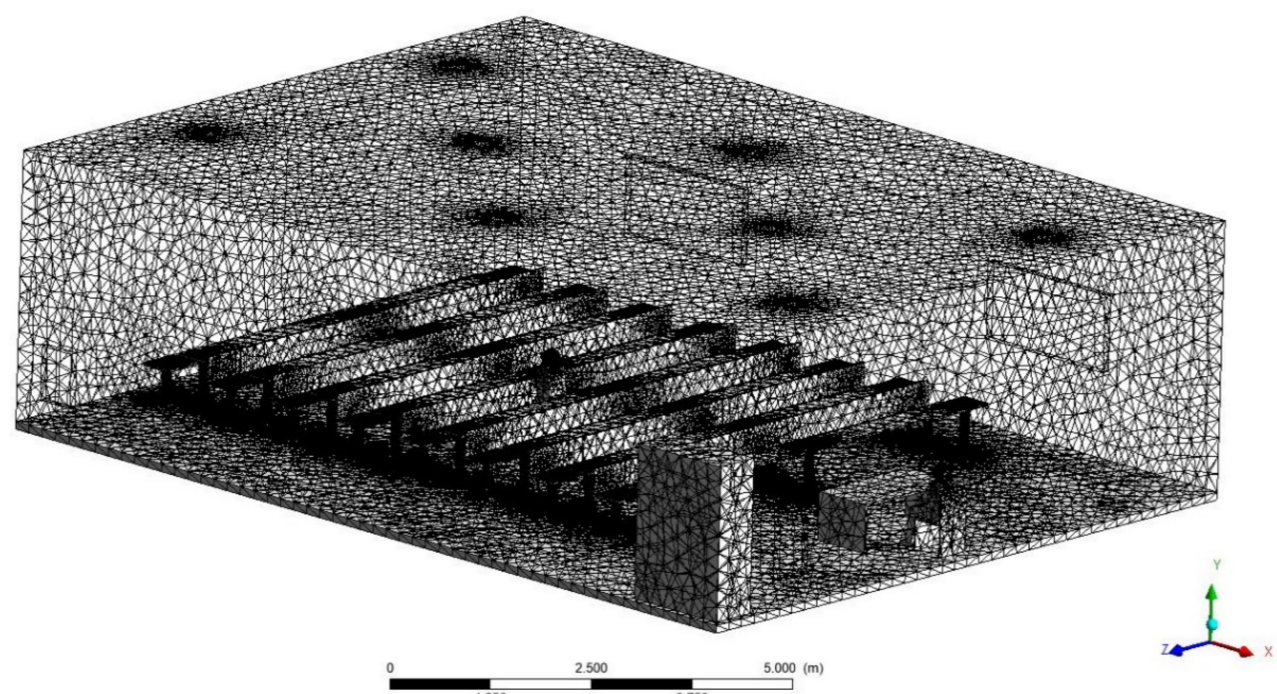

Figure 6. Mesh of a typical class model.

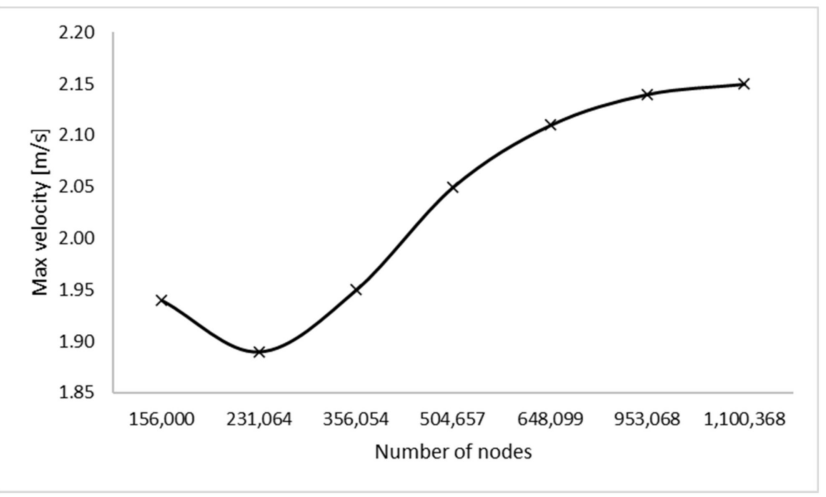

(a)

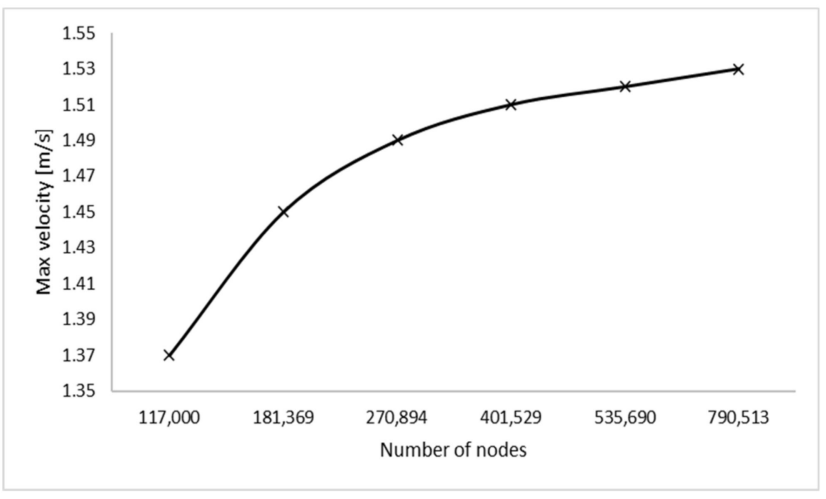

(b)

Figure 7. Mesh sensitivity analysis: (a) Office; (b) Class.

Table 3. Mesh details in the selected case studies.

\begin{tabular}{ccccc}
\hline Case Study & Nodes & Elements (Tetrahedra) & Skewness & Orthogonal Qiality \\
\hline Office & 648,099 & $3,567,162$ & 0.23 & 0.85 \\
Class & 535,690 & $2,725,893$ & 0.24 & 0.85 \\
\hline
\end{tabular}

Table 4. Model solution setup details.

\begin{tabular}{|c|c|c|c|c|c|}
\hline Item & \multicolumn{5}{|c|}{ Solution Setup } \\
\hline \multirow{3}{*}{ Solver } & \multicolumn{3}{|c|}{ Type } & \multicolumn{2}{|c|}{ Pressure based } \\
\hline & \multicolumn{3}{|c|}{ Velocity formulation } & \multicolumn{2}{|c|}{ Absolute } \\
\hline & \multicolumn{3}{|c|}{ Gravity } & \multicolumn{2}{|c|}{-9.81} \\
\hline \multirow{4}{*}{ Time } & \multirow{2}{*}{$\begin{array}{l}\text { Airflow } \\
\text { analysis }\end{array}$} & \multirow{2}{*}{ Steady } & \multirow{2}{*}{ Iteration } & Office & 1300 \\
\hline & & & & Class & 1300 \\
\hline & \multirow{2}{*}{$\begin{array}{l}\text { Discrete } \\
\text { analysis }\end{array}$} & \multirow{2}{*}{ Transient } & \multirow{2}{*}{$\begin{array}{l}\text { Time step (s)/Number of } \\
\text { time step/Max Iteration }\end{array}$} & Office & $1 / 1800 / 20$ \\
\hline & & & & Class & $1 / 1800 / 20$ \\
\hline
\end{tabular}


Table 4. Cont.

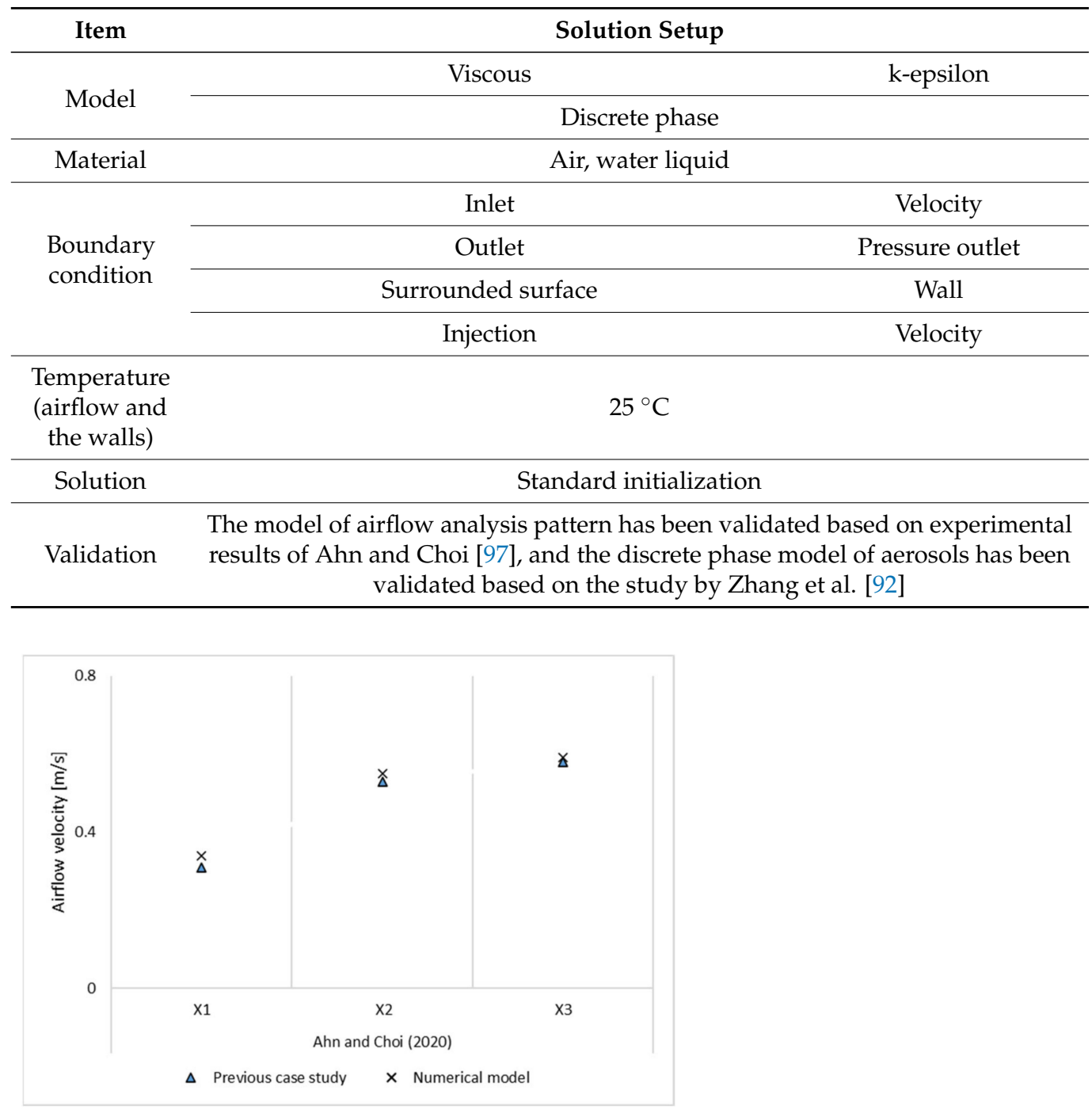

Figure 8. Validation of the developed models according to the previous similar case studies.

\section{Results and Discussion}

\subsection{The Results of the CFD Model}

In this section, at first, the airflow streamline patterns in the selected office and classroom have been analyzed, and the trajectory of the aerosols and $\mathrm{ACH}$ in two cases of open and closed windows has been investigated.

\subsubsection{Indoor Airflow Patterns and the Impacts of Inlet/Outlet, Windows Locations}

The airflow path and the direction of airflows are essential factors that could influence the trajectory of aerosols and, in the case of contaminated aerosols, might negatively affect the safe distance between two occupants inside an office or classroom and thus should be taken into consideration. The airflow patterns in the selected case studies are shown in Figures 9-12. 

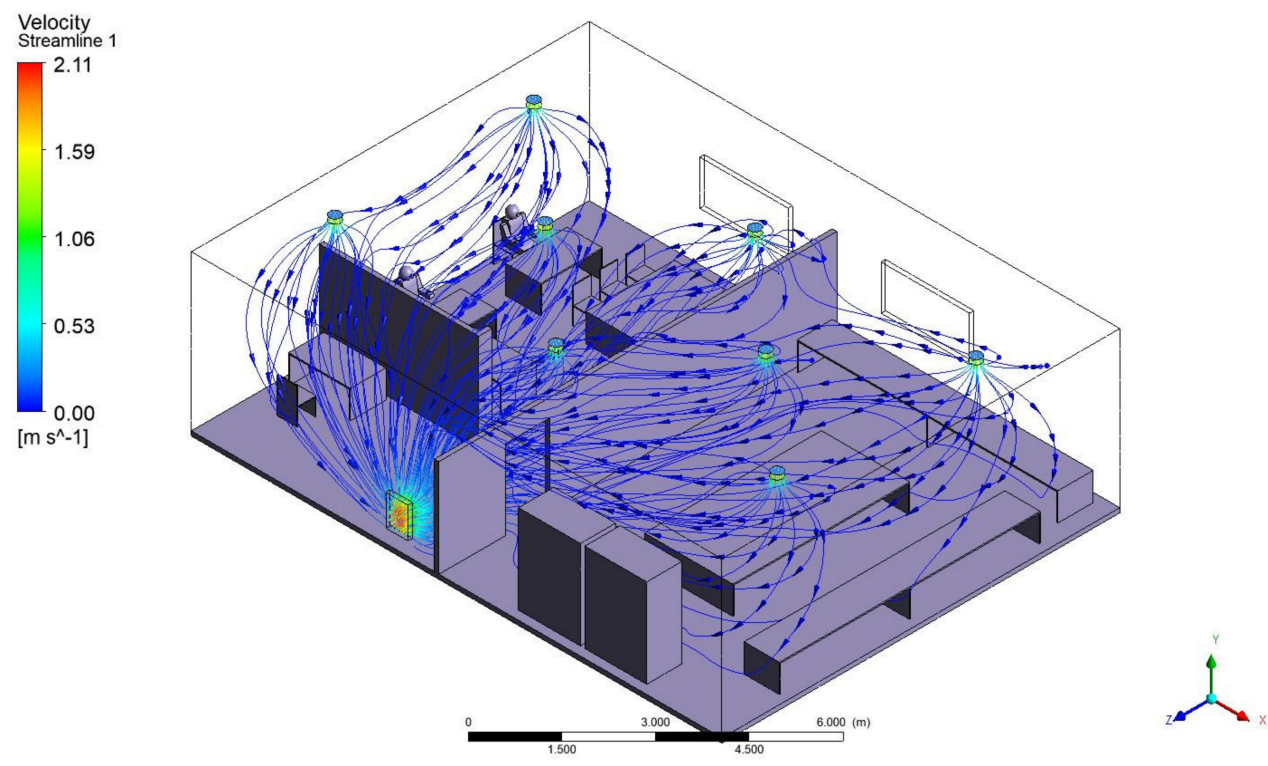

Figure 9. Airflow streamlines pattern in the typical office with closed windows.
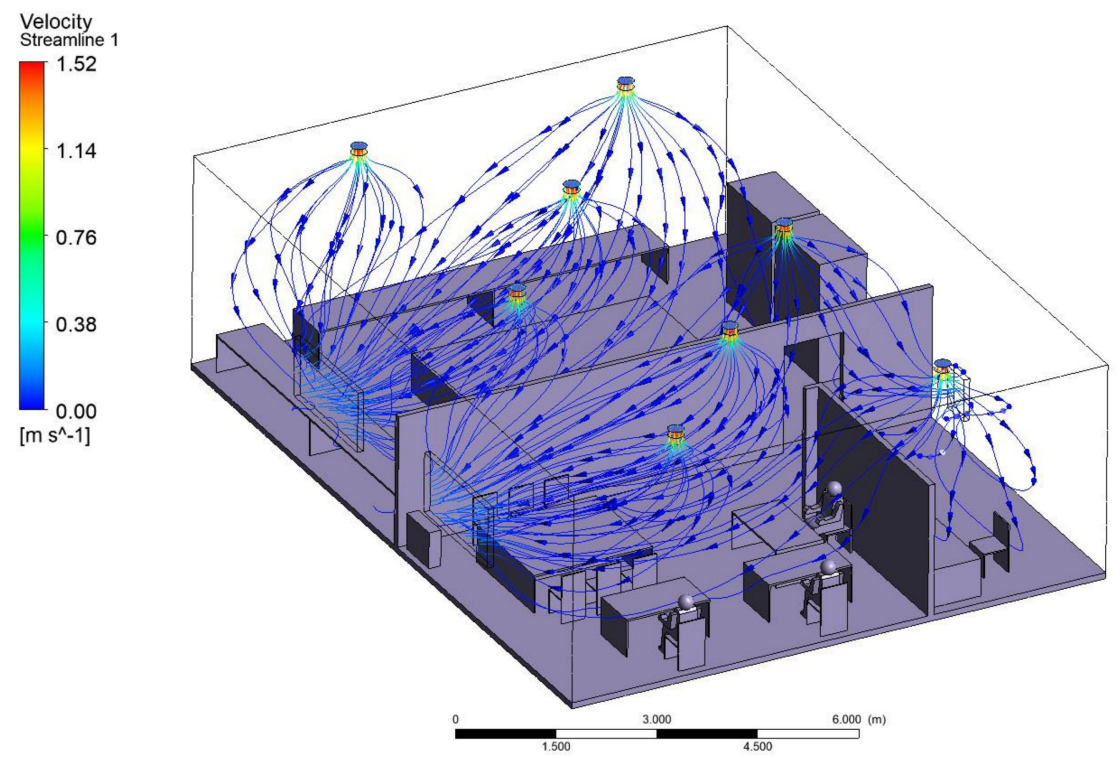

Figure 10. Airflow streamlines pattern in the typical office with open windows. 


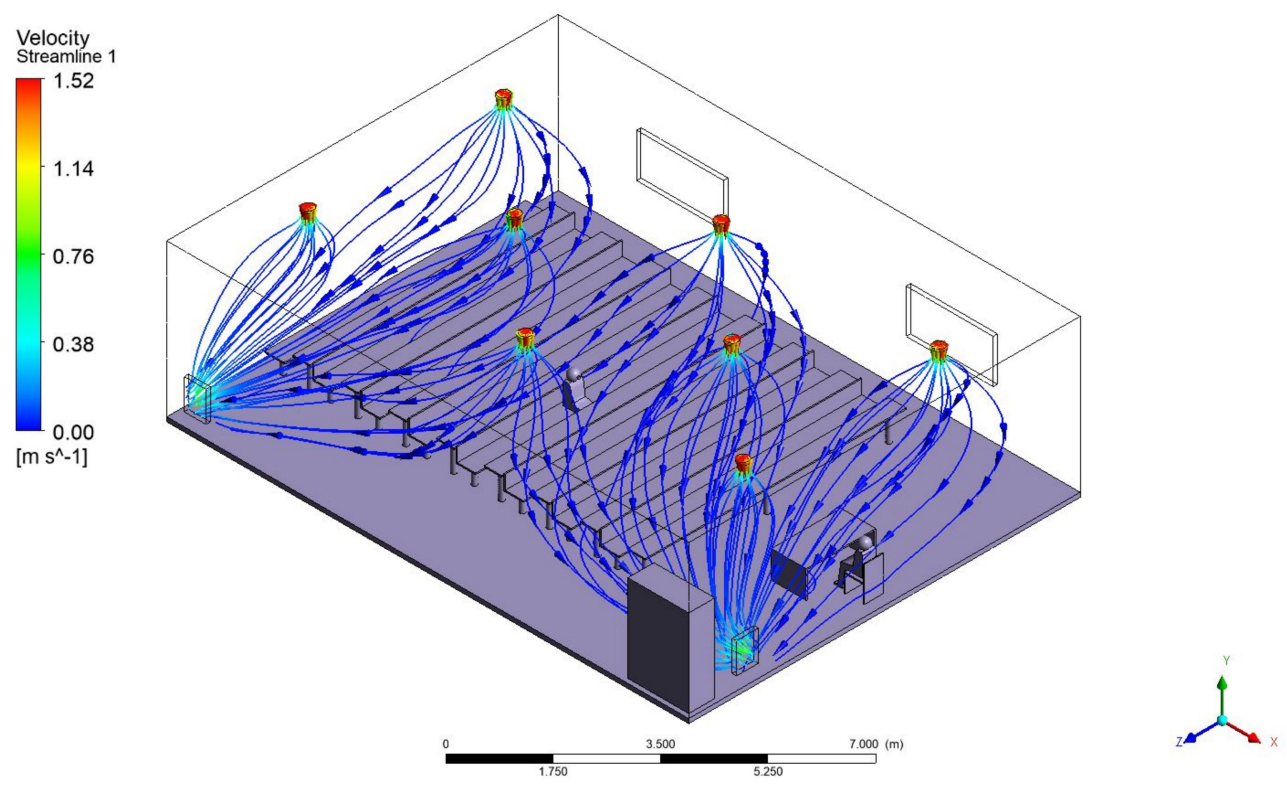

Figure 11. Airflow streamlines pattern in the typical classroom with closed windows.

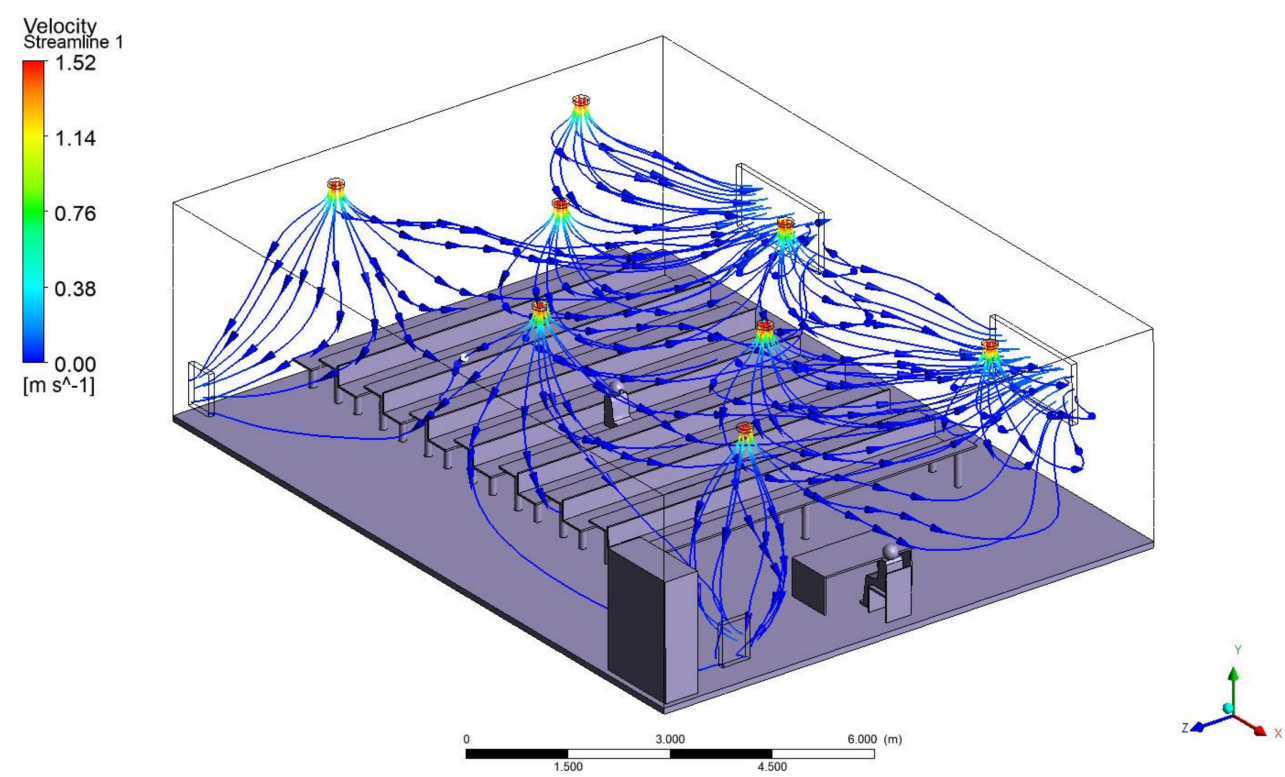

Figure 12. Airflow streamlines pattern in the typical classroom with open windows.

4.1.2. $\mathrm{ACH}$ in the Indoor Environments and the Impact of Dead Zones

Using CFD modeling could also determine the dead zones (areas with low airflow speed). The full $\mathrm{ACH}$ can change by increasing the dead zones, the air quality could be lesser in the dead zones, and the contamination load could be higher. The dead zones are determined in the dark blue color in Figures 13 and 14. The dead zones could be minimized by CFD simulation and by changing the locations of the inlets/outlets in the rooms. 

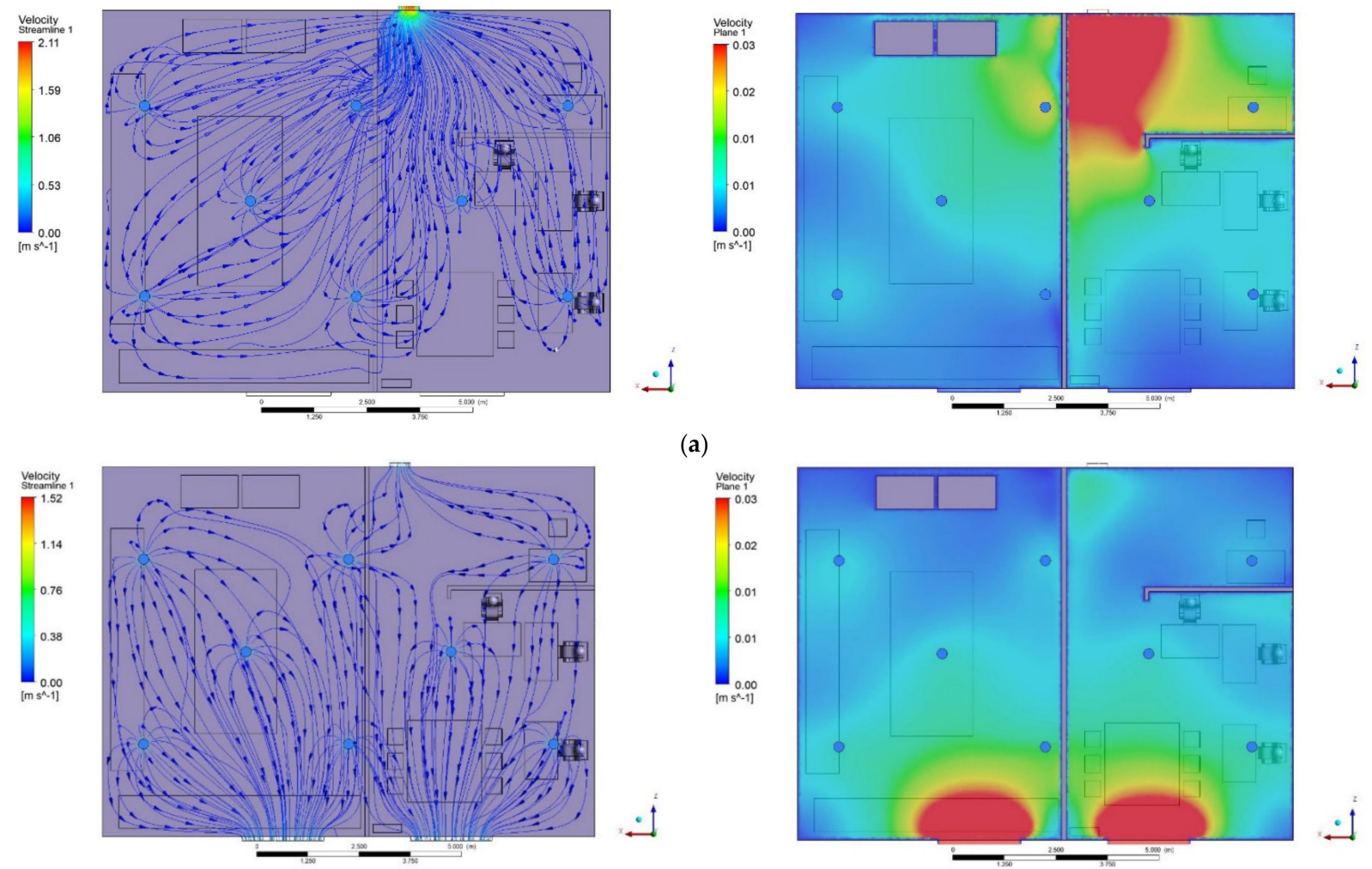

(b)

Figure 13. Dead zones with very low airflow speed in the typical office: (a) Closed windows; (b) Open windows.
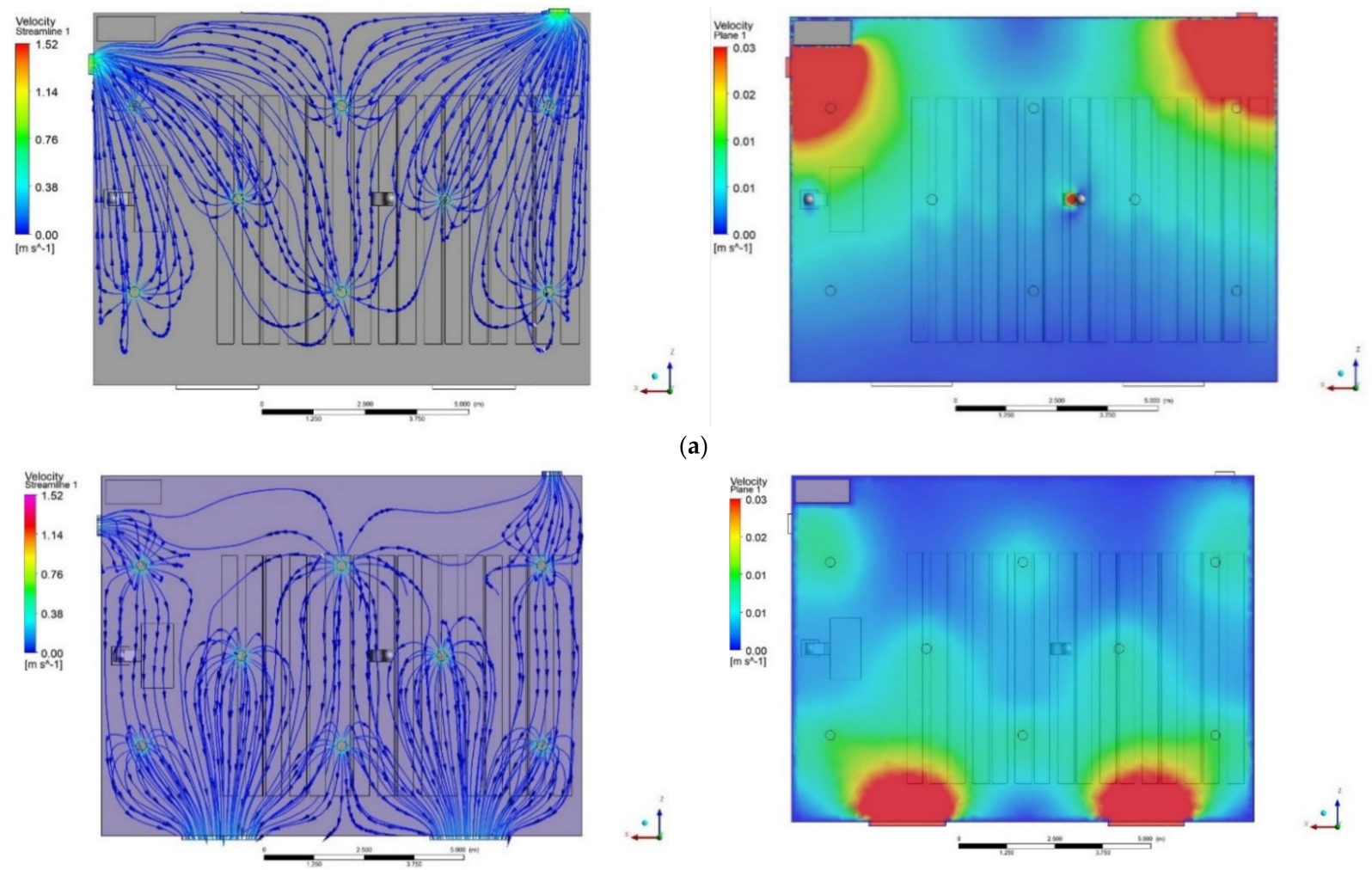

(a)

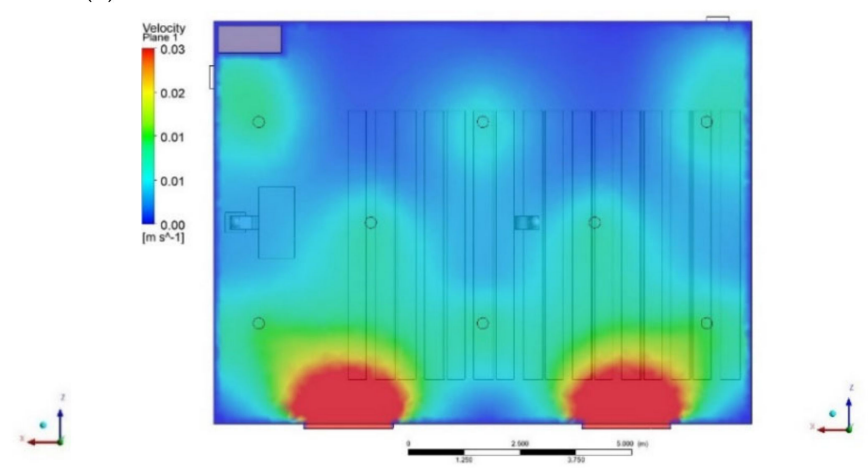

(b)

Figure 14. Dead zones with very low airflow speed in the typical classroom: (a) Closed windows; (b) Open windows. 


\subsubsection{ACH and the Impact of Windows on the Trajectory of Contaminated Aerosols}

The results of discrete phase in office and class with open and closed windows are shown in Figures 15-18, and videos S1 and S2 in the Supplementary Materials. The figures exhibit the particle traces, and the dots represent the remaining particles (aerosols) in the mentioned times (s).

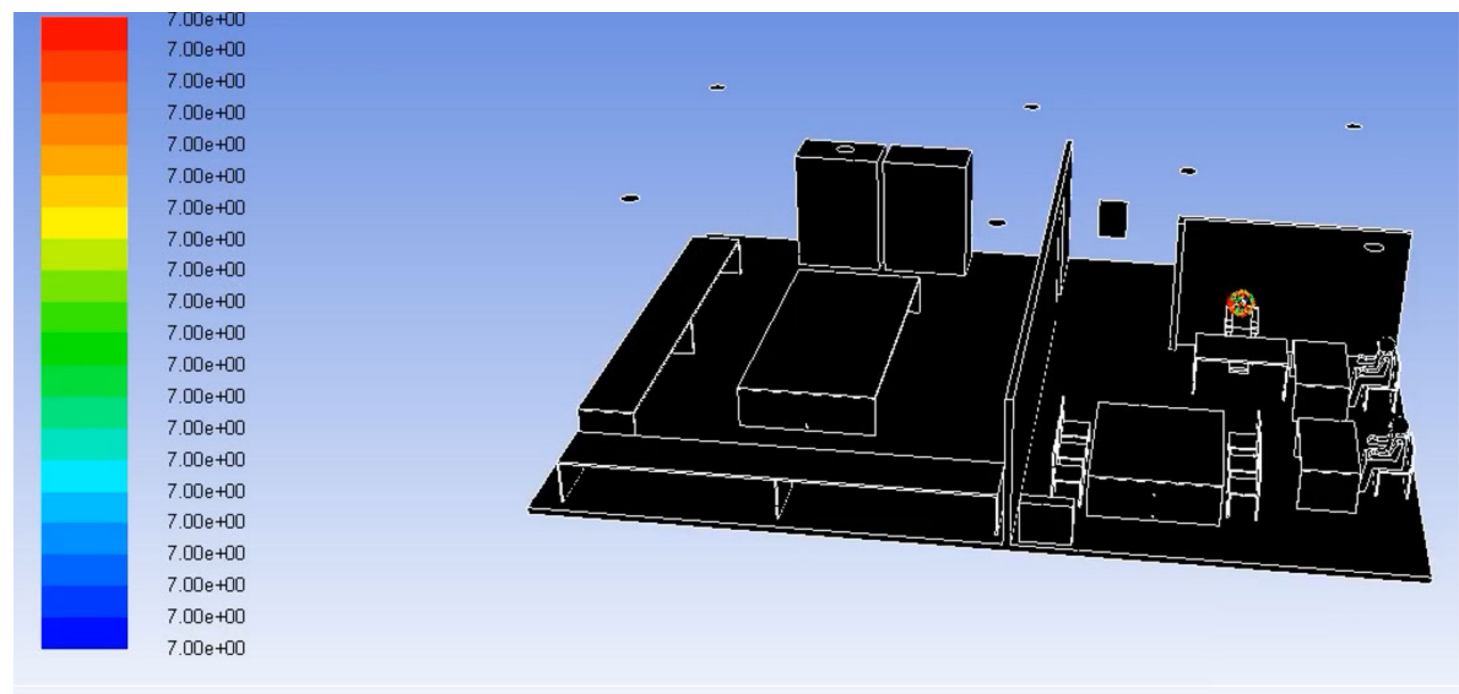

Particle Traces Colored by Particle Residence Time (s) (Time=1.0000e+01)

(a)

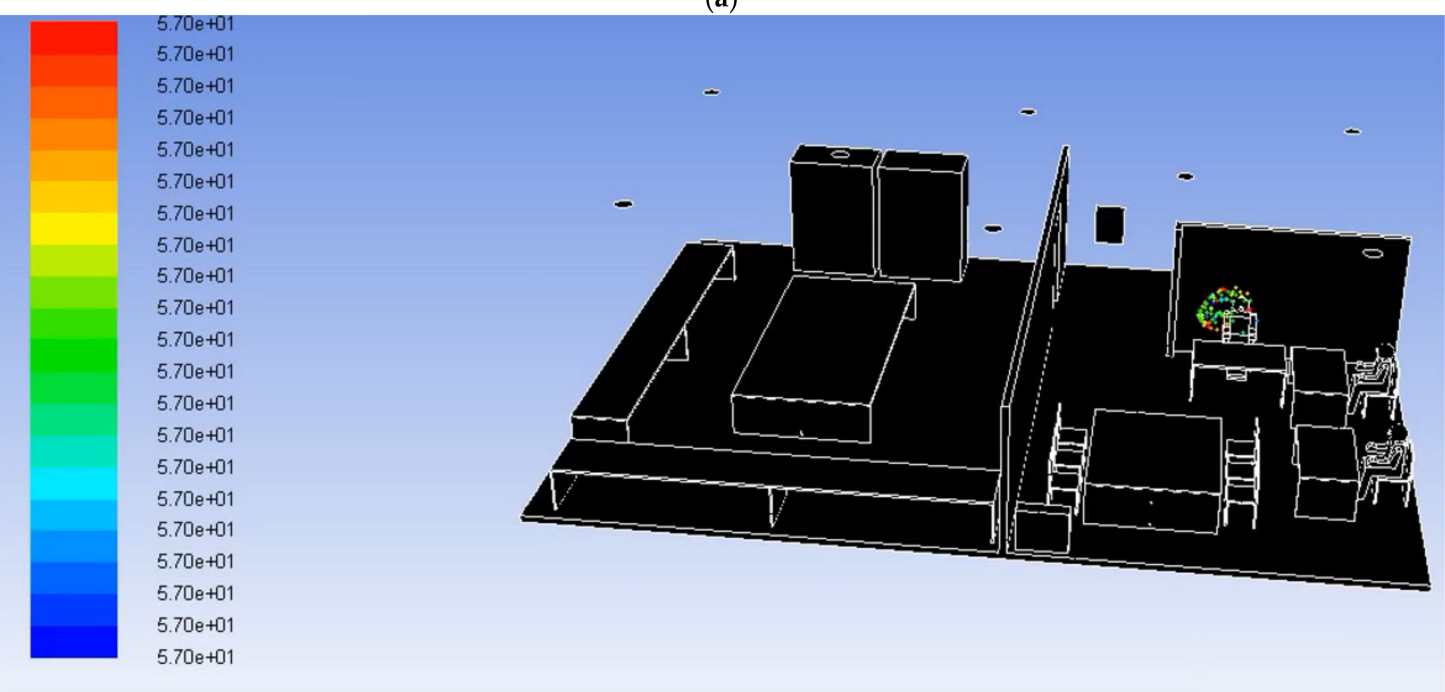

Particle Traces Colored by Particle Residence Time (s) (Time $=6.0000 \mathrm{e}+01)$

(b)

Figure 15. Cont. 


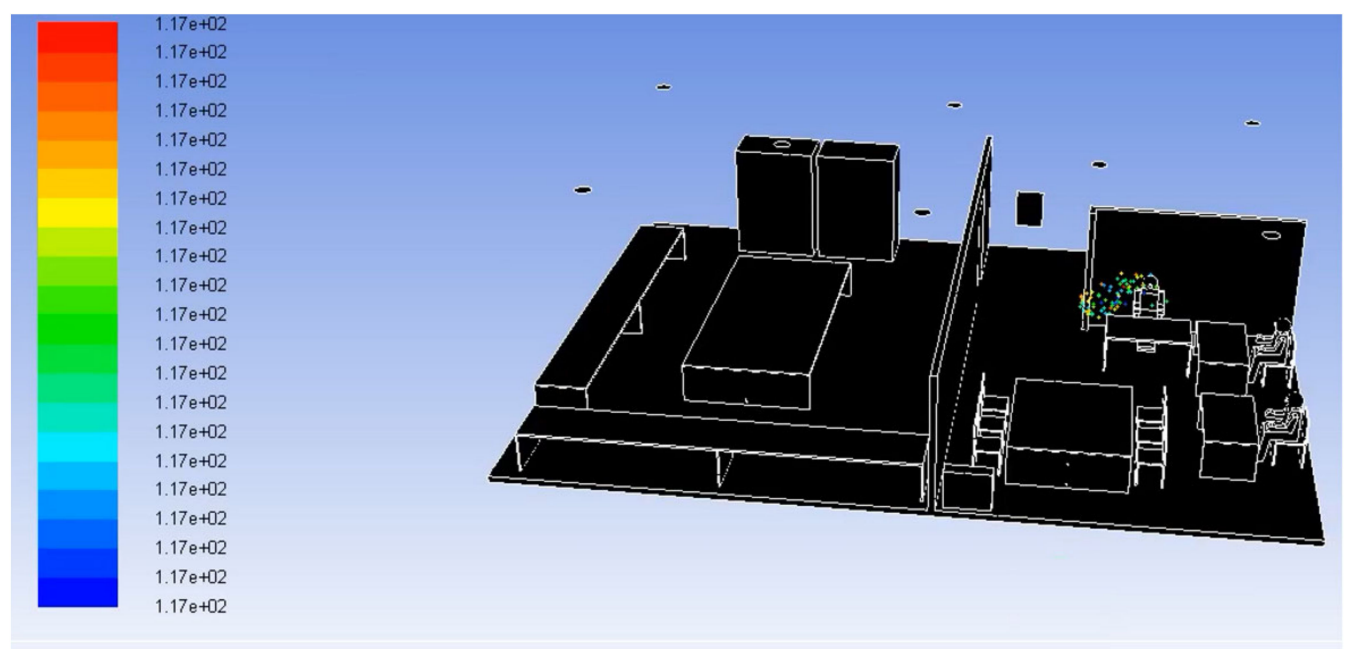

Particle Traces Colored by Particle Residence Time (s) (Time=1.2000e+02)

(c)

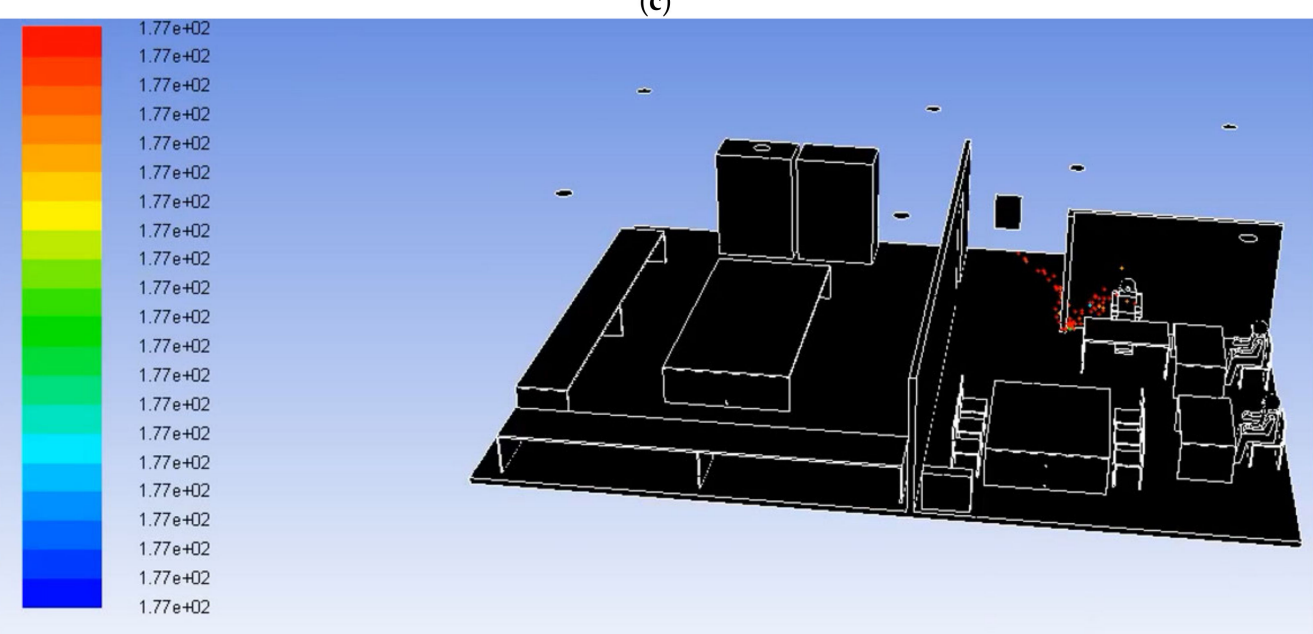

Particle Traces Colored by Particle Residence Time (s) (Time=1.8000e+02)

(d)

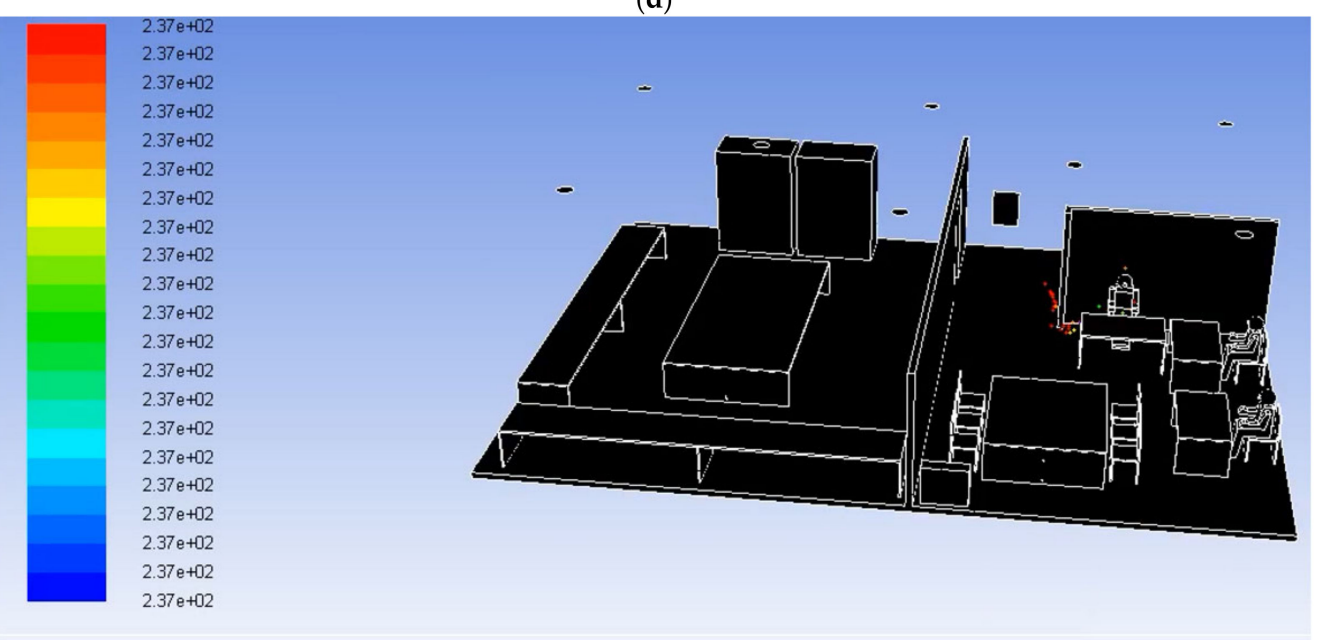

Particle Traces Colored by Particle Residence Time (s) (Time $=2.4000 \mathrm{e}+02)$

(e)

Figure 15. Discrete phase modelling of the office with closed windows: (a) $10 \mathrm{~s}$; (b) $60 \mathrm{~s}$; (c) $120 \mathrm{~s}$; (d) $180 \mathrm{~s}$; (e) $240 \mathrm{~s}$. 


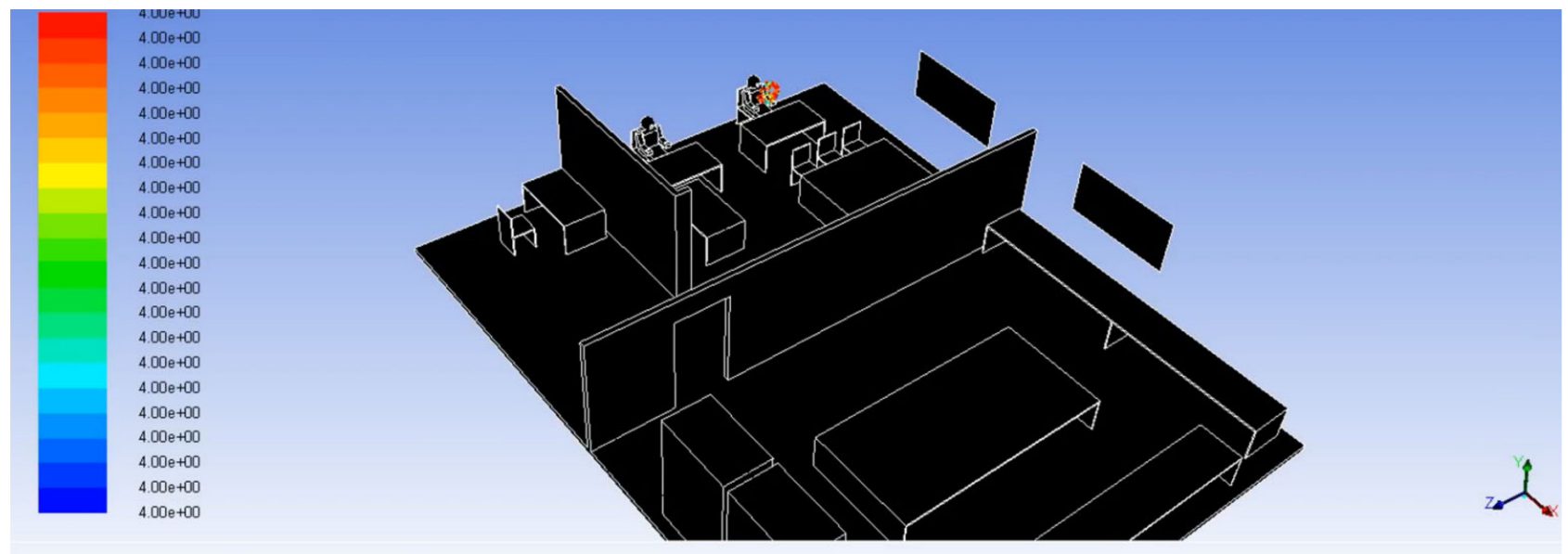

Particle Traces Colored by Particle Residence Time (s) (Time $=1.0000 \mathrm{e}+01)$

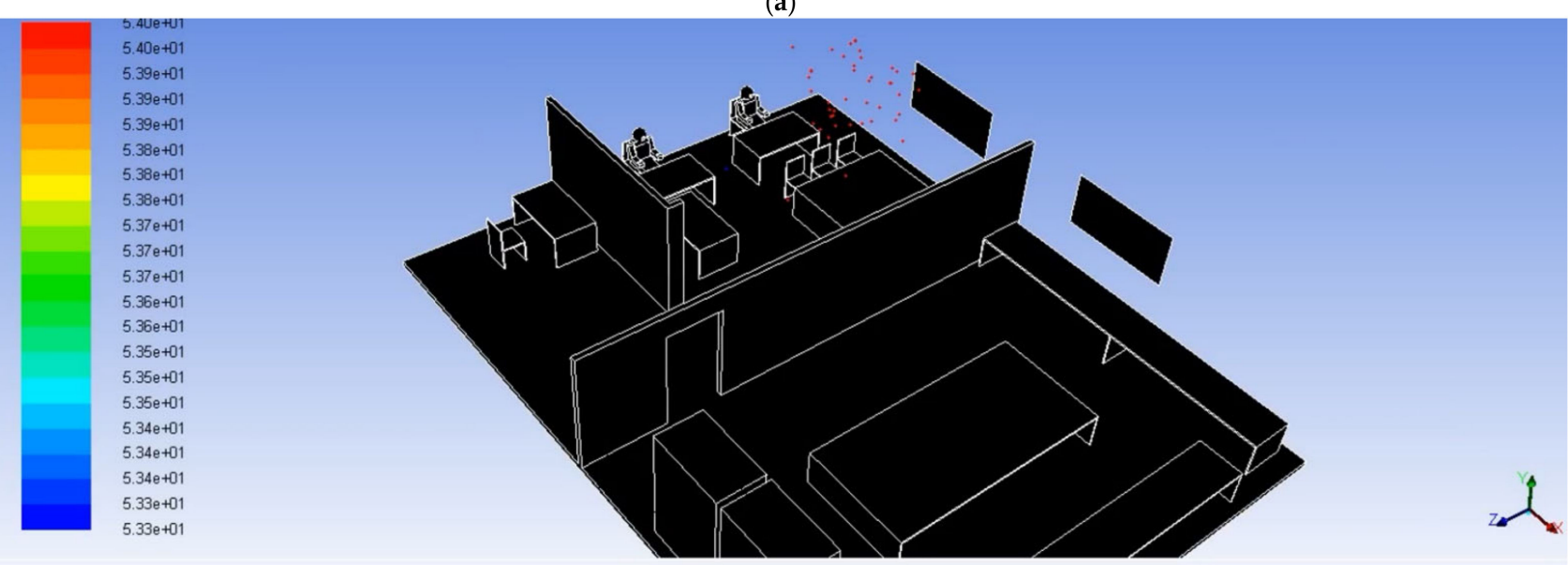

Particle Traces Colored by Particle Residence Time (s) $($ Time $=6.0000 \mathrm{e}+01)$

(b)

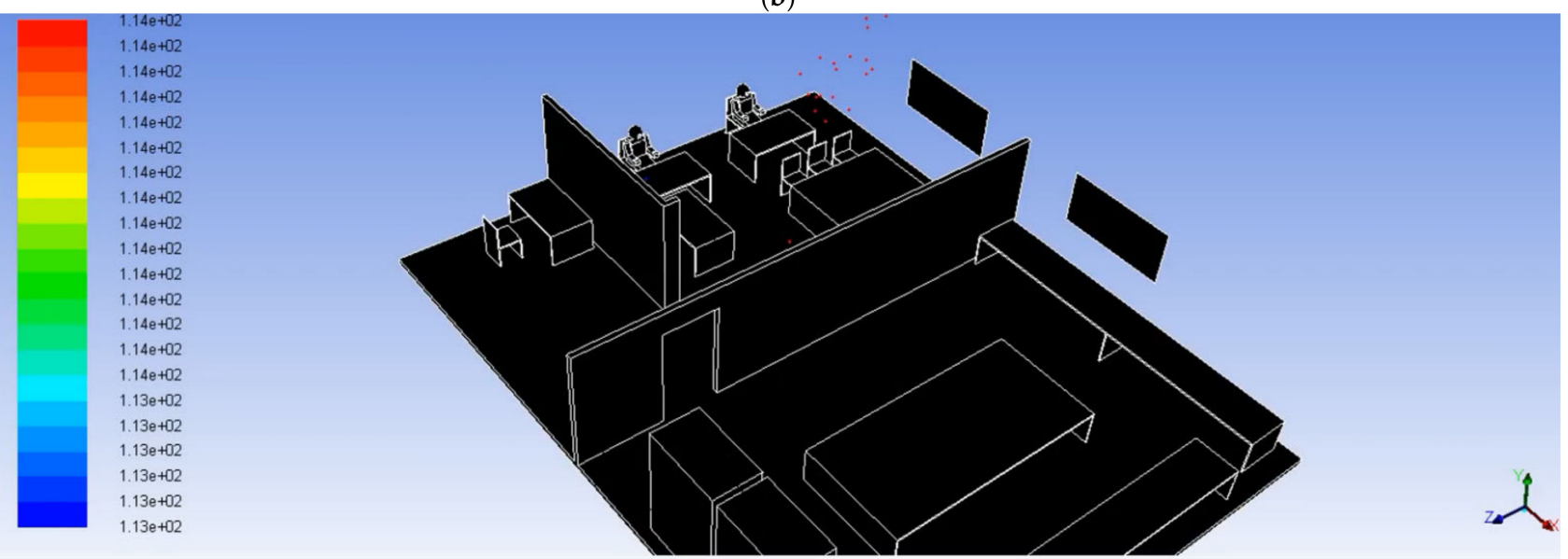

Particle Traces Colored by Particle Residence Time (s) (Time=1.2000e+02)

(c)

Figure 16. Cont. 


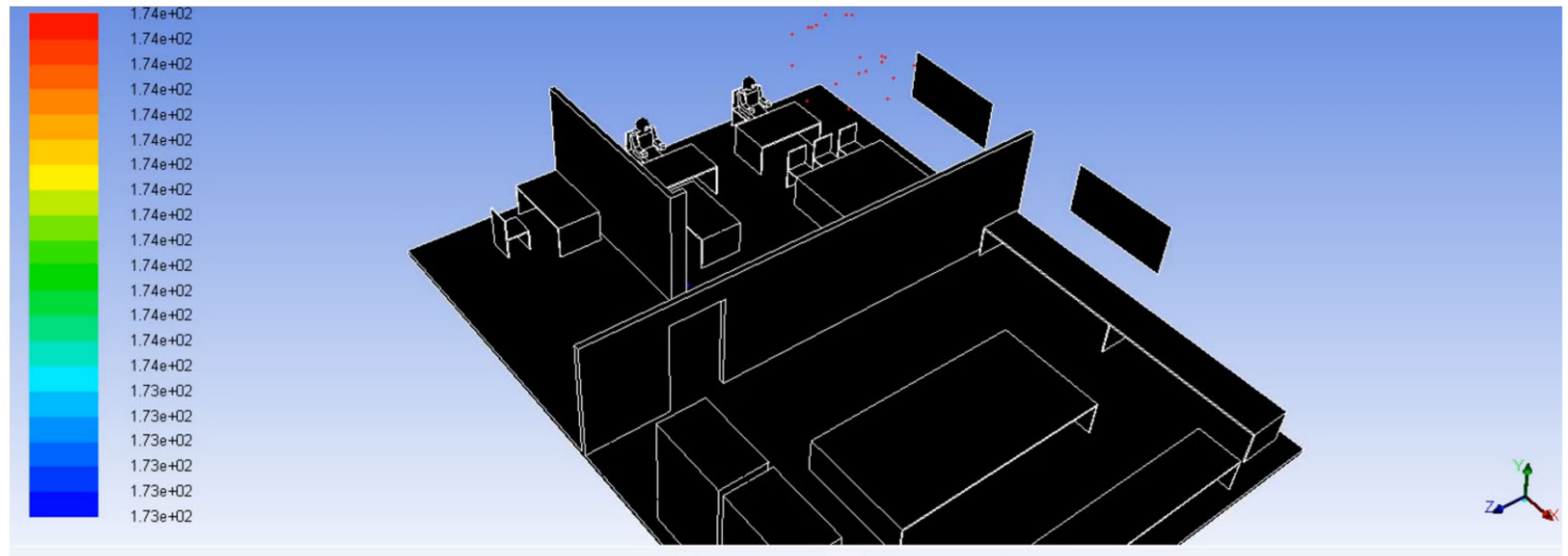

Particle Traces Colored by Particle Residence Time (s) (Time=1.8000e+02)

(d)

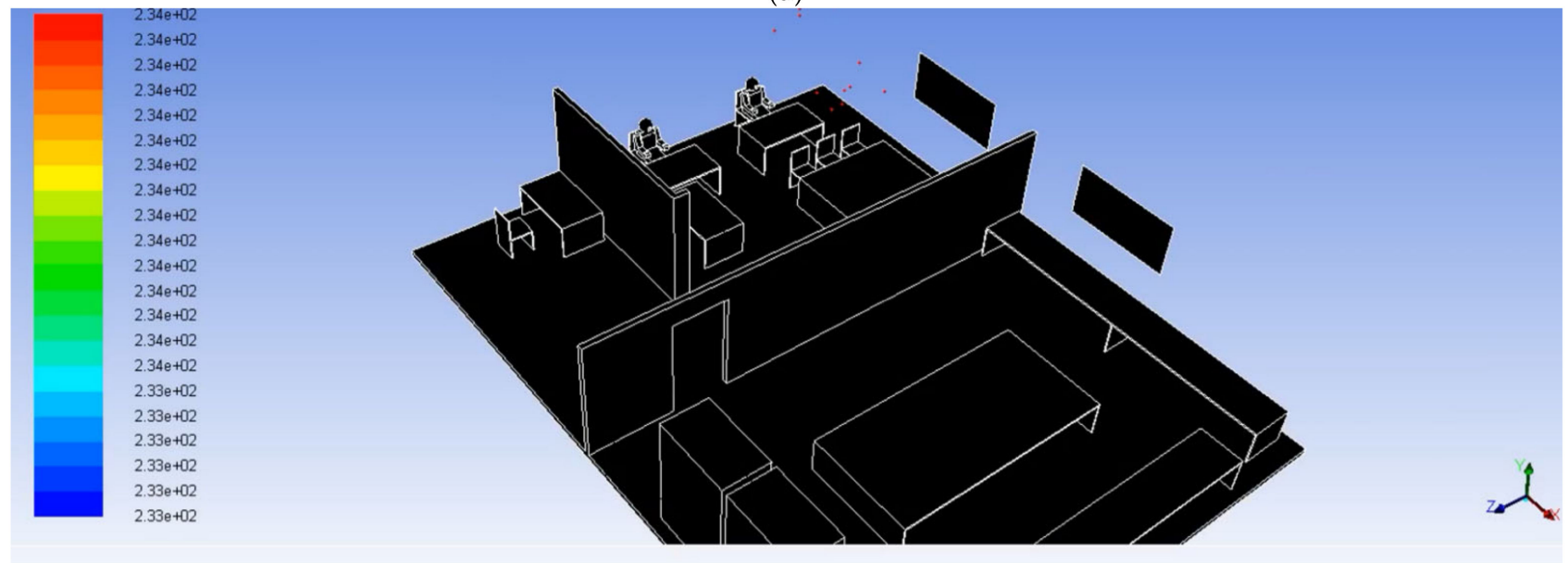

(e)

Figure 16. Discrete phase modelling of the office with open windows: (a) $10 \mathrm{~s}$; (b) $60 \mathrm{~s}$; (c) $120 \mathrm{~s}$; (d) $180 \mathrm{~s}$; (e) $240 \mathrm{~s}$. 


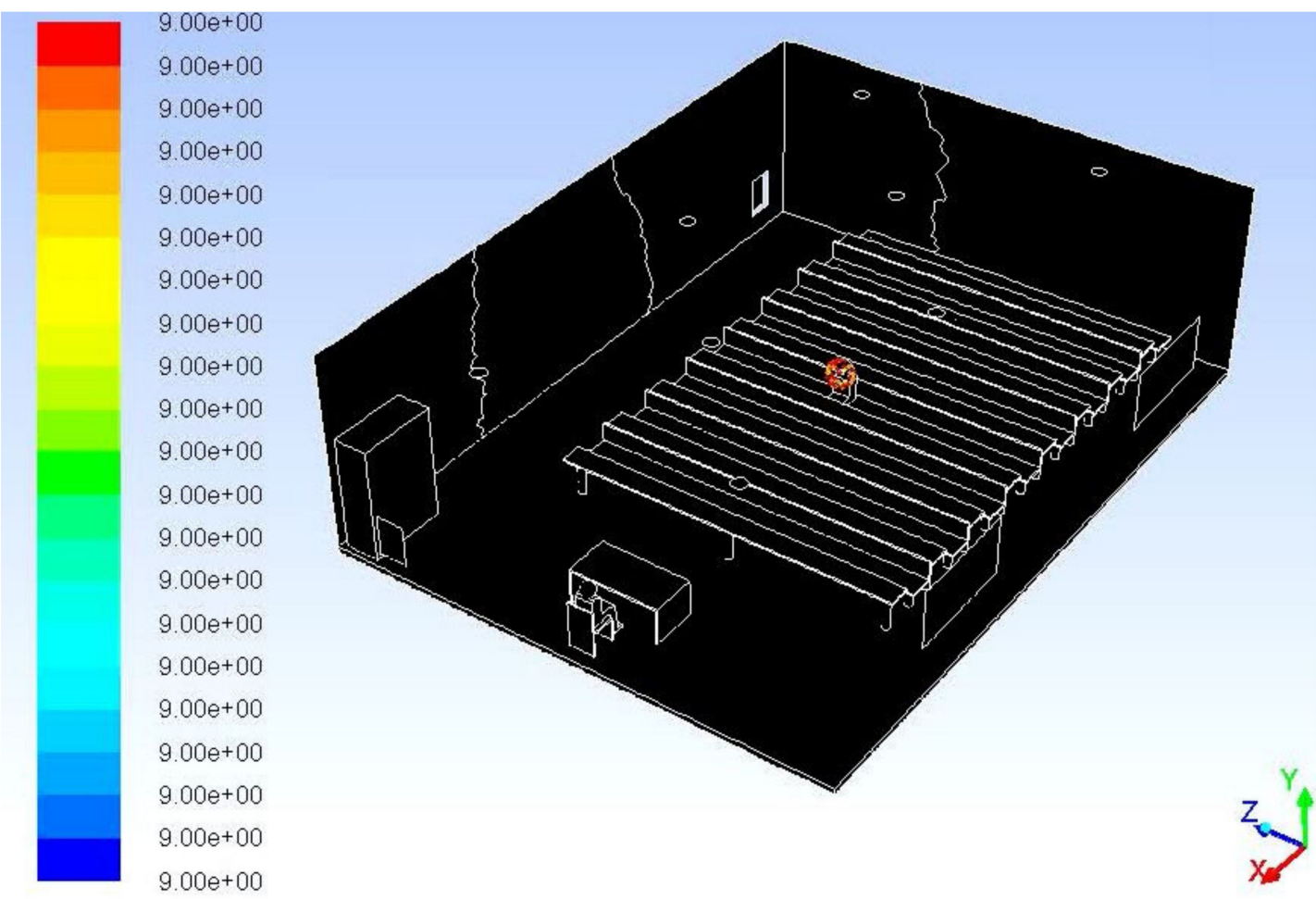

Particle Traces Colored by Particle Residence Time (s) $($ Time $=1.0000 e+01)$

(a)

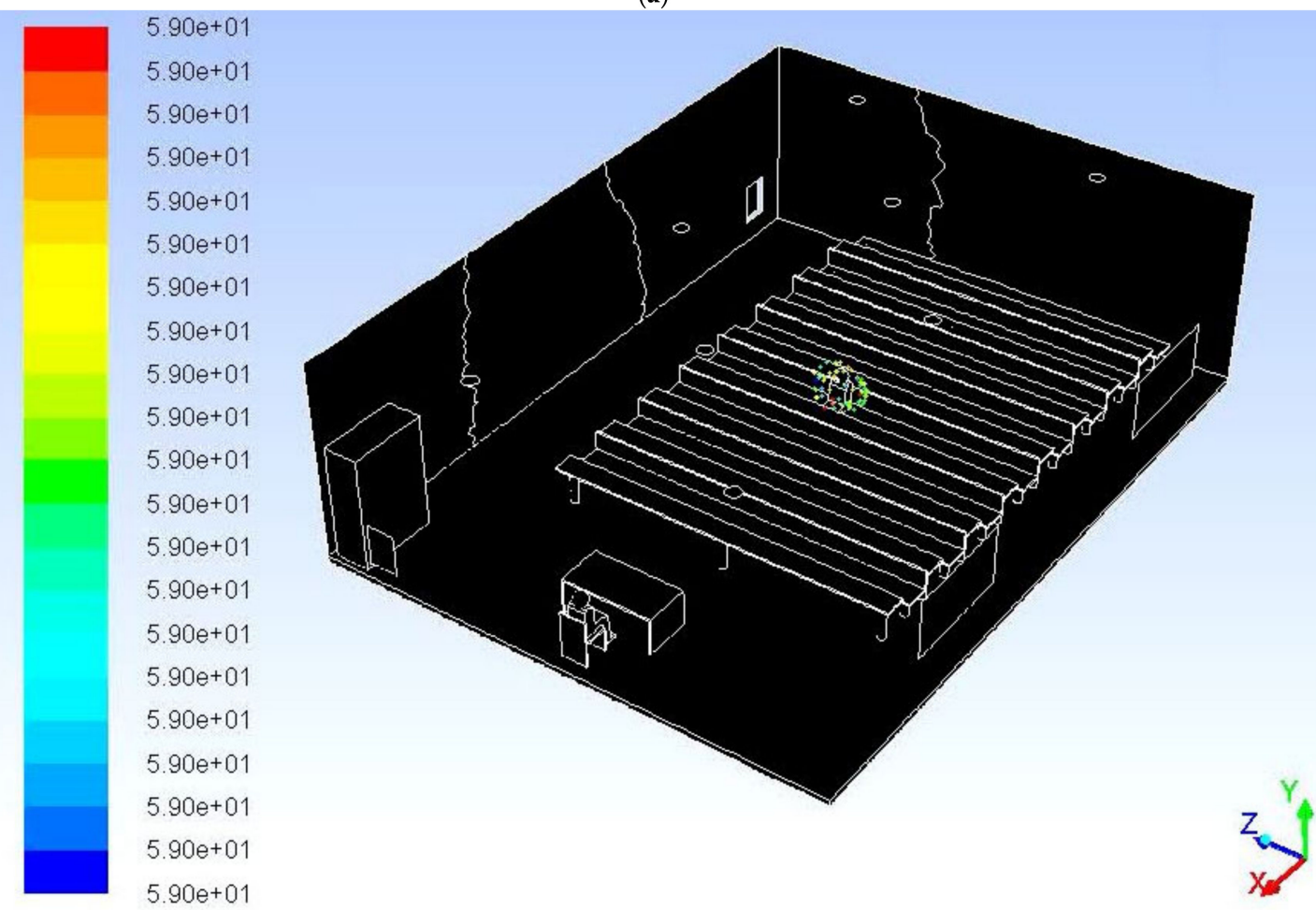

Particle Traces Colored by Particle Residence Time (s) $($ Time $=6.0000 e+01)$

(b)

Figure 17. Cont. 


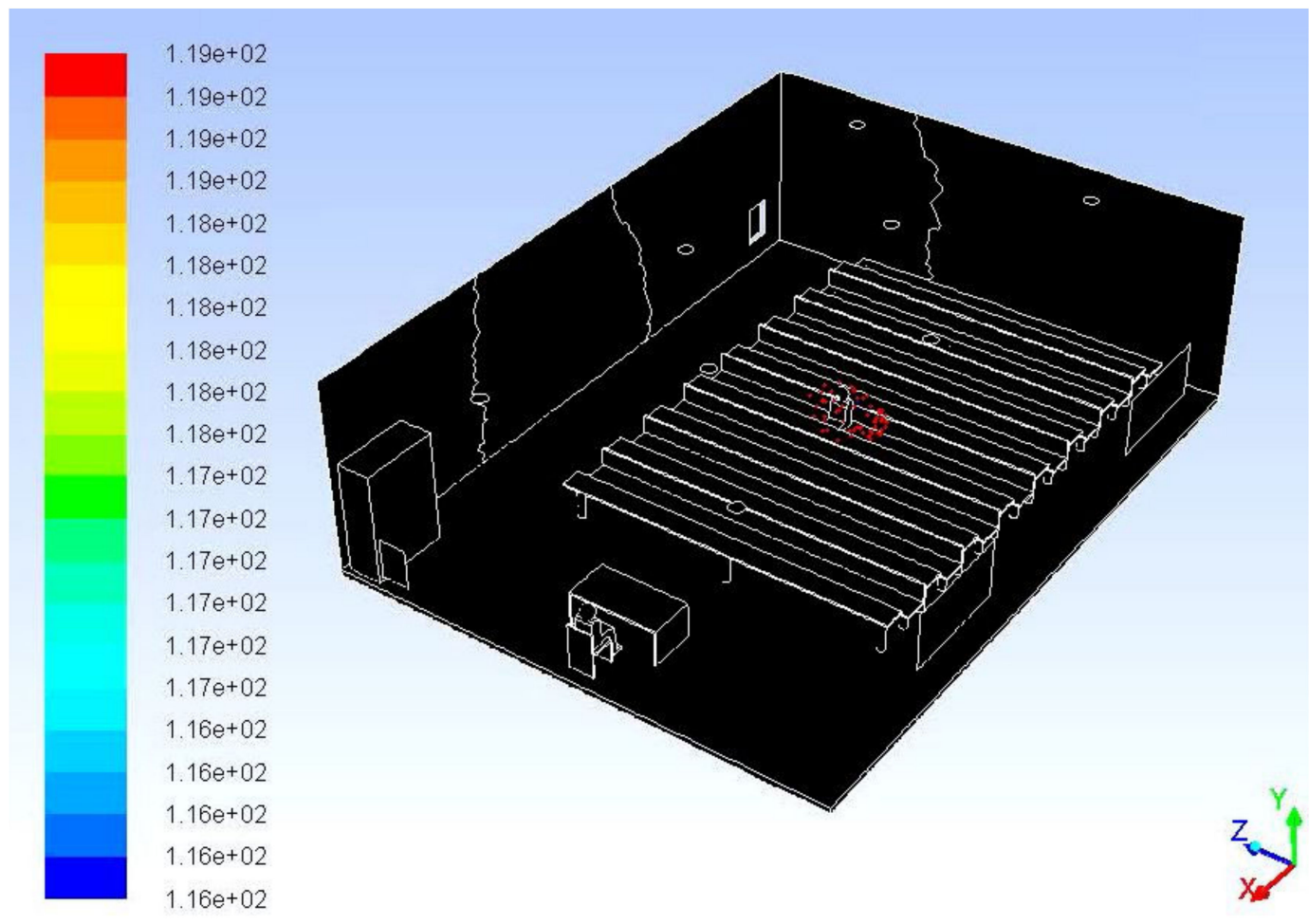

Particle Traces Colored by Particle Residence Time (s) $($ Time $=1.2000 \mathrm{e}+02)$

(c)

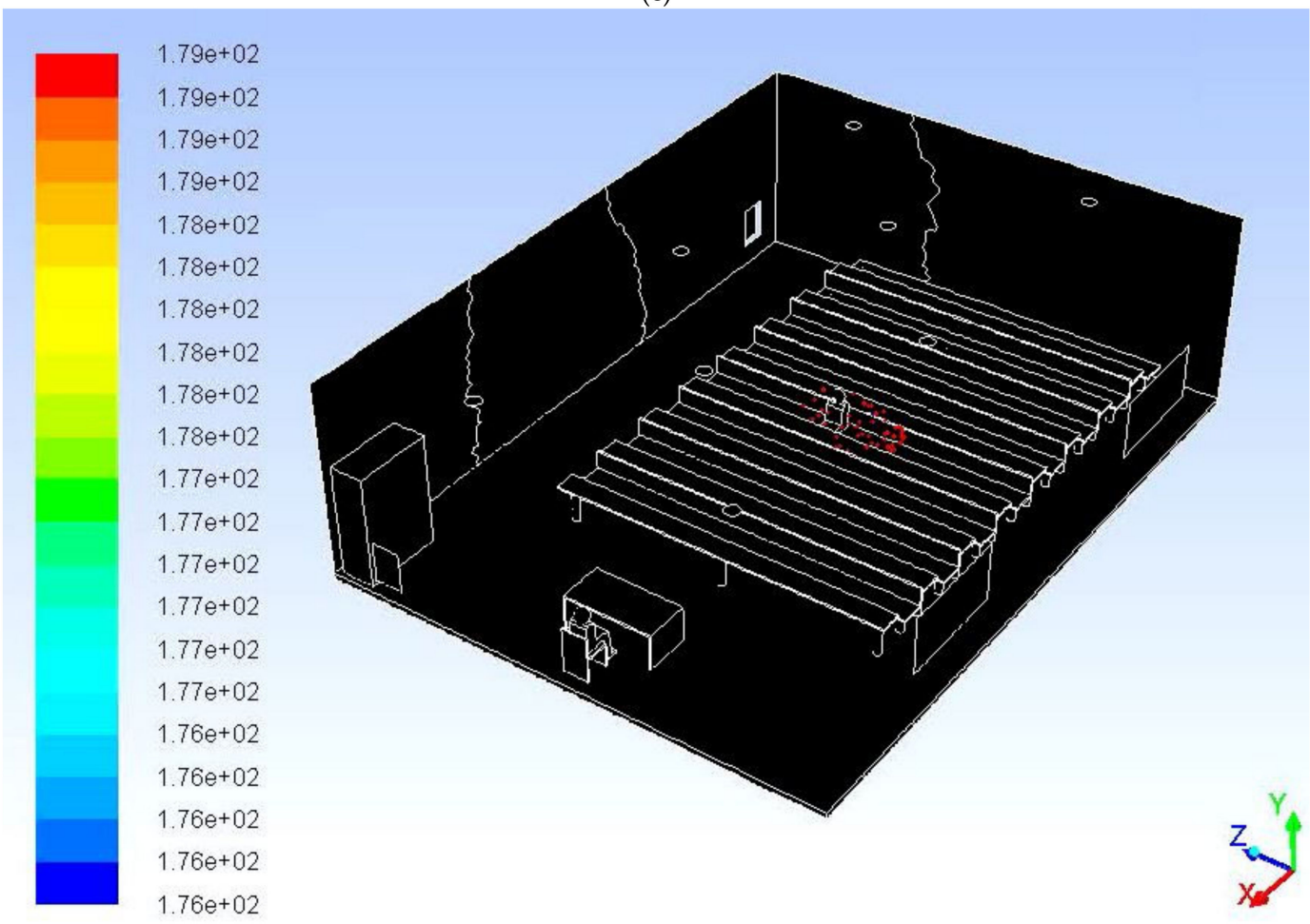

Particle Traces Colored by Particle Residence Time (s) $($ Time $=1.8000 \mathrm{e}+02)$

(d)

Figure 17. Cont. 


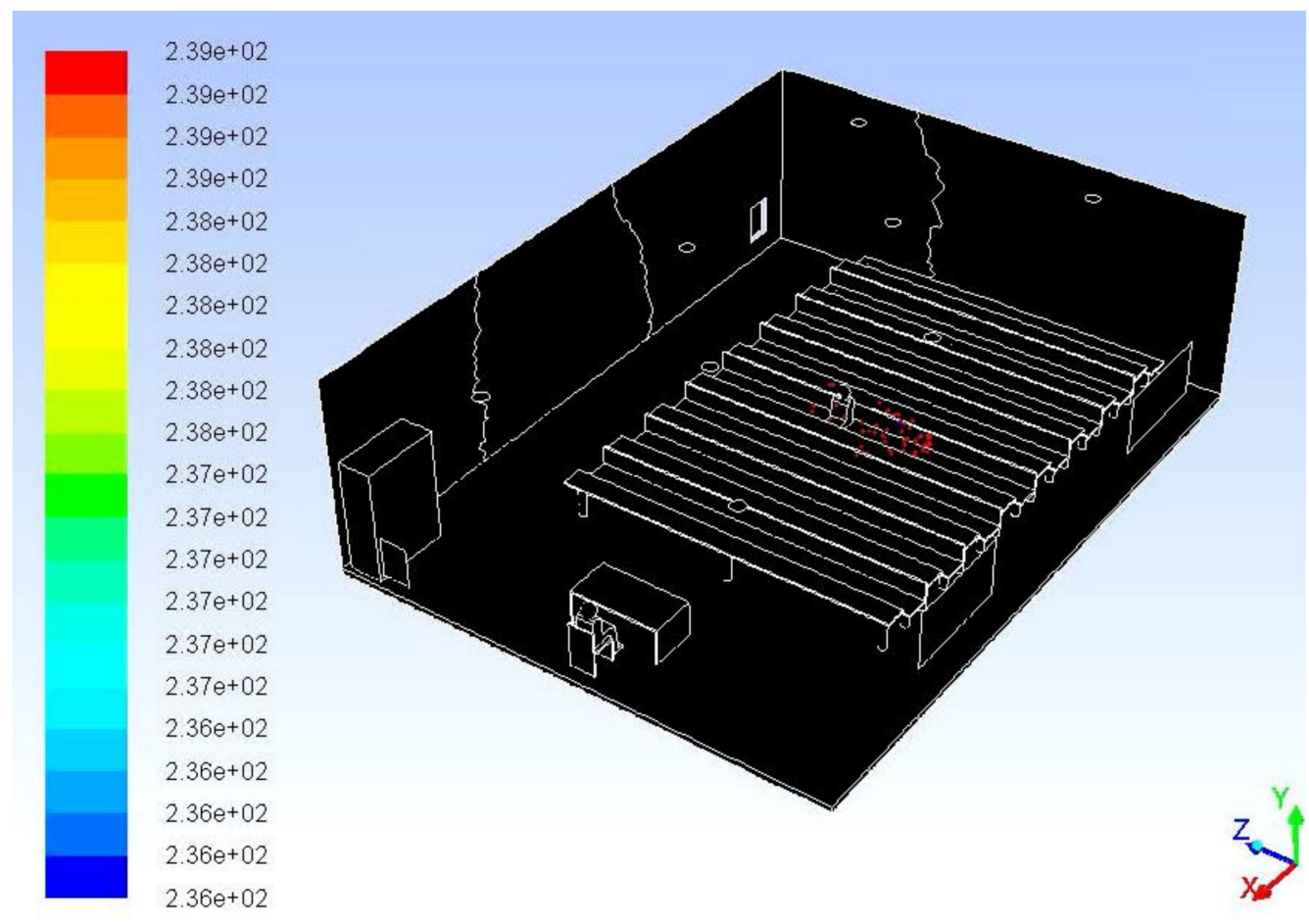

Particle Traces Colored by Particle Residence Time (s) (Time=2.4000e+02)

(e)

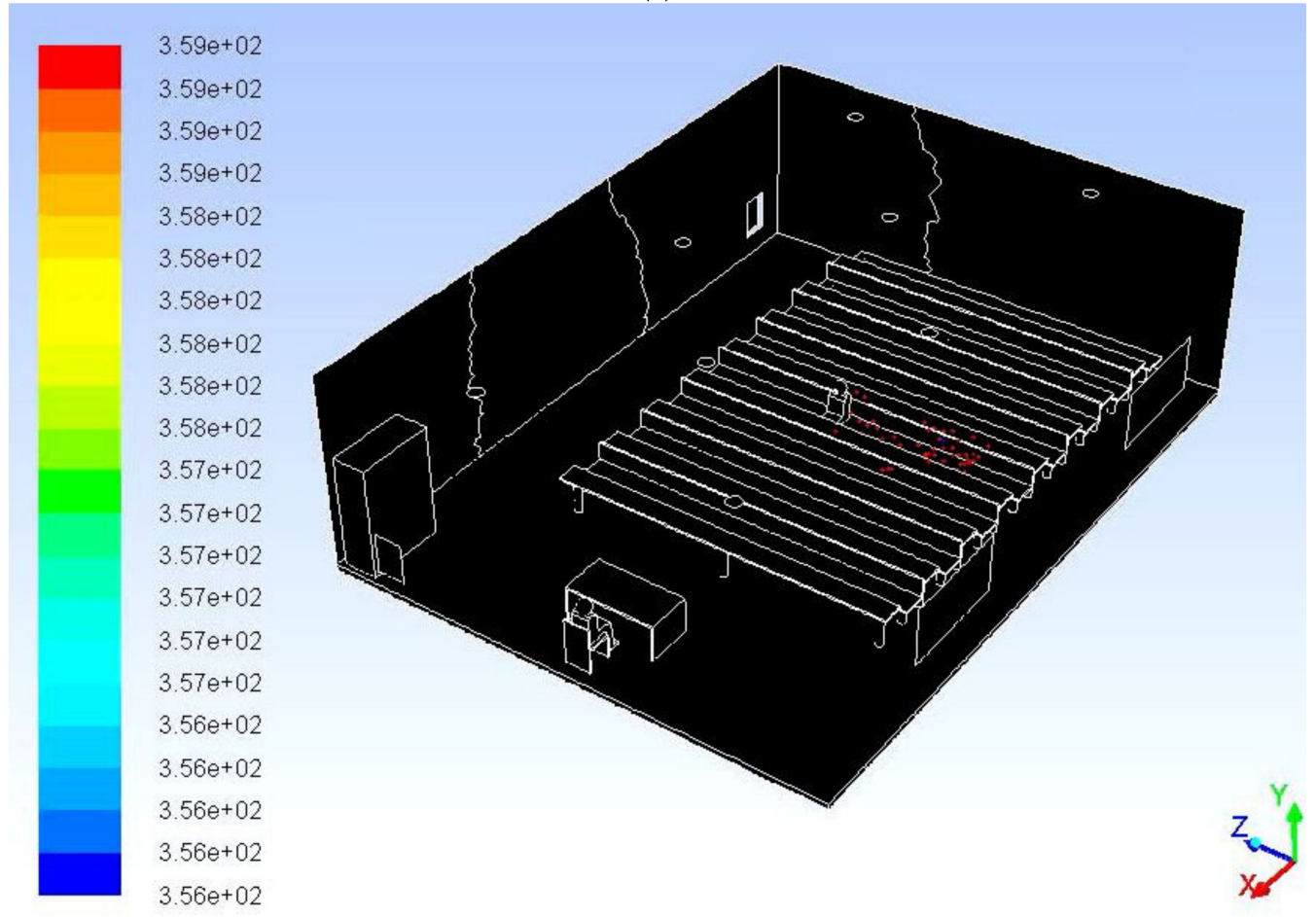

Particle Traces Colored by Particle Residence Time (s) (Time=3.6000e+02)

(f)

Figure 17. Discrete phase modelling of the classroom with closed windows: (a) $10 \mathrm{~s}$; (b) $60 \mathrm{~s}$; (c) $120 \mathrm{~s}$; (d) $180 \mathrm{~s}$; (e) $240 \mathrm{~s}$; (f) $360 \mathrm{~s}$. 


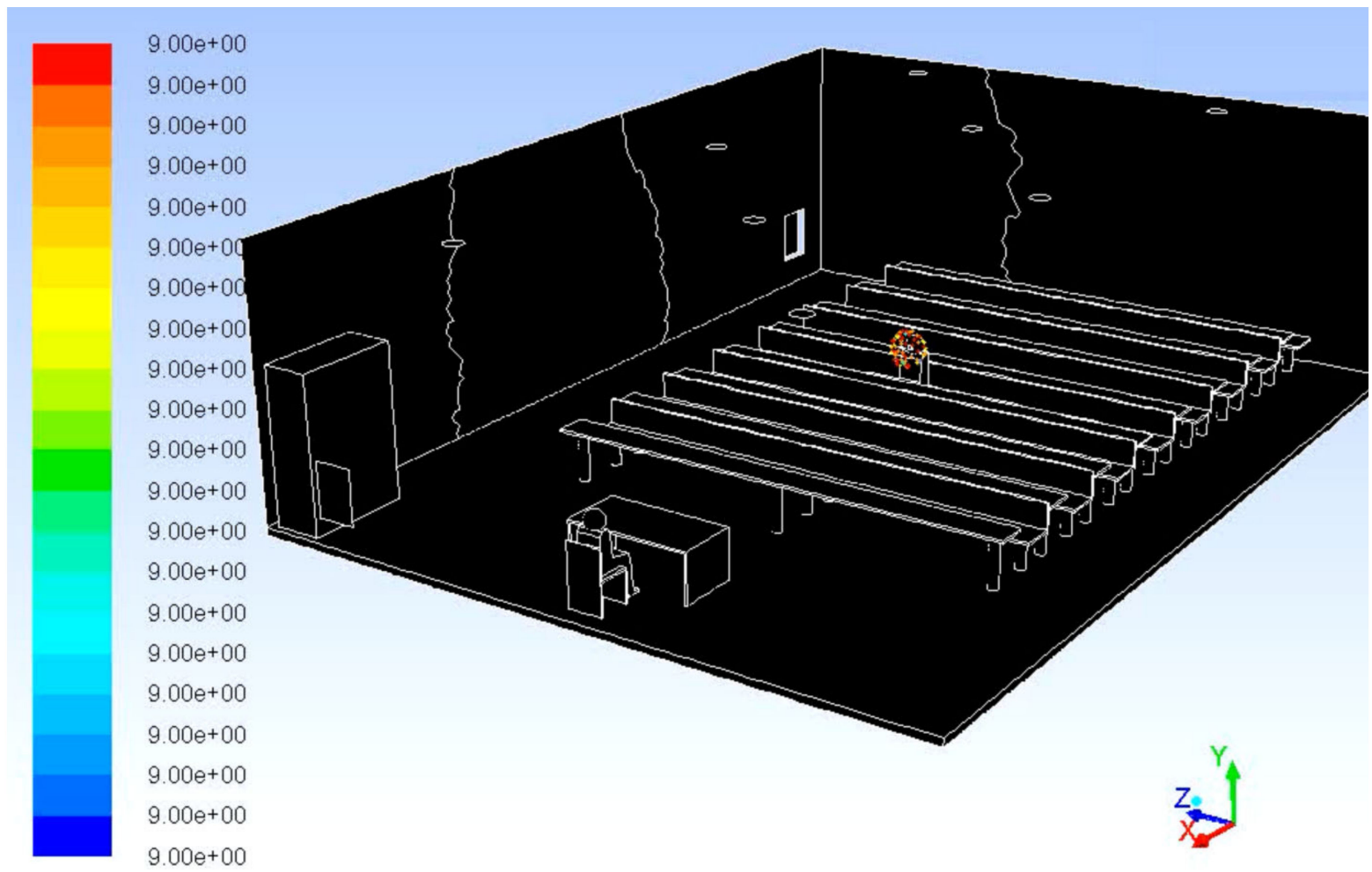

Particle Traces Colored by Particle Residence Time (s) (Time=1.0000e+01)

(a)

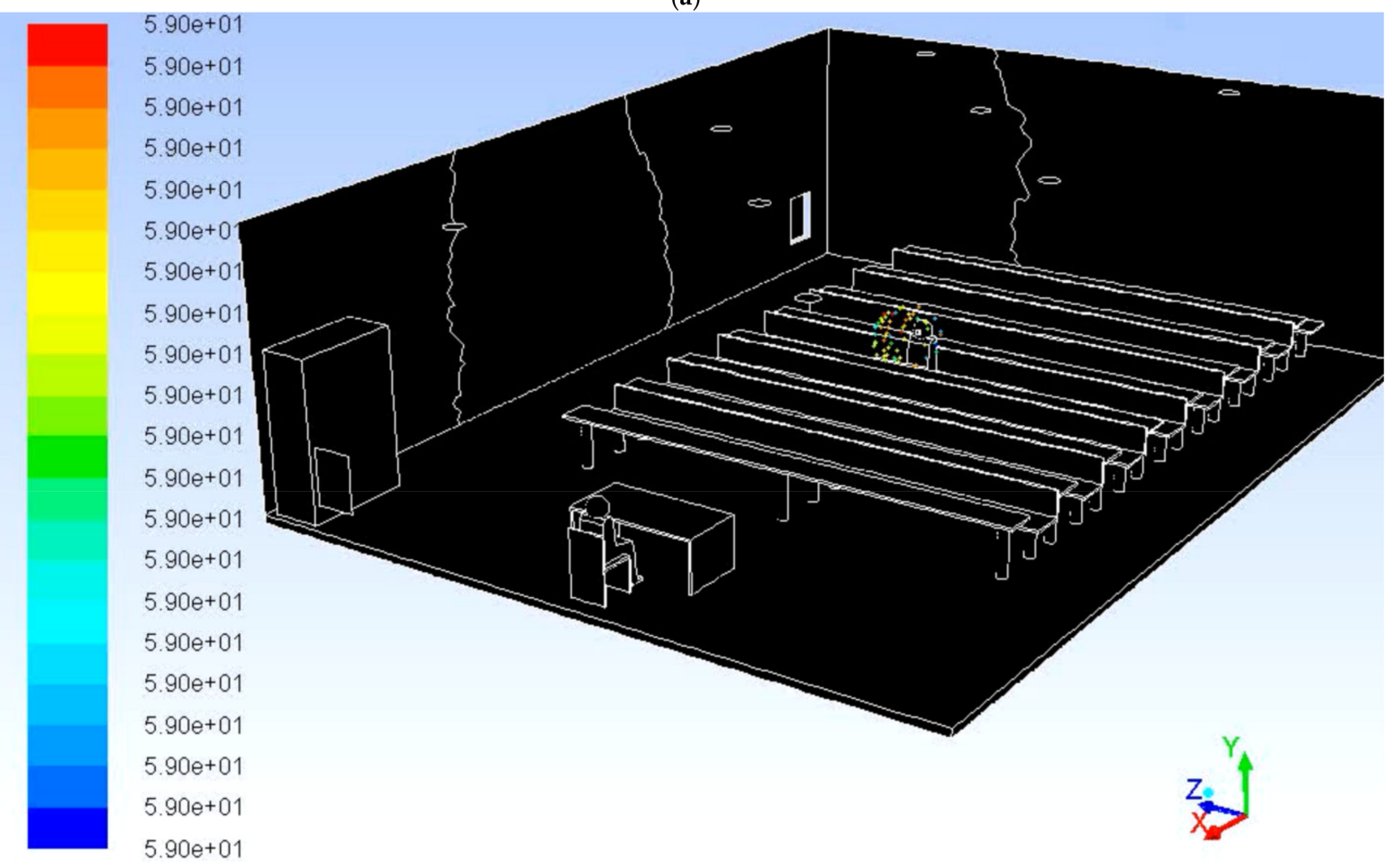

Particle Traces Colored by Particle Residence Time (s) $($ Time $=6.0000 \mathrm{e}+01)$

(b)

Figure 18. Cont. 


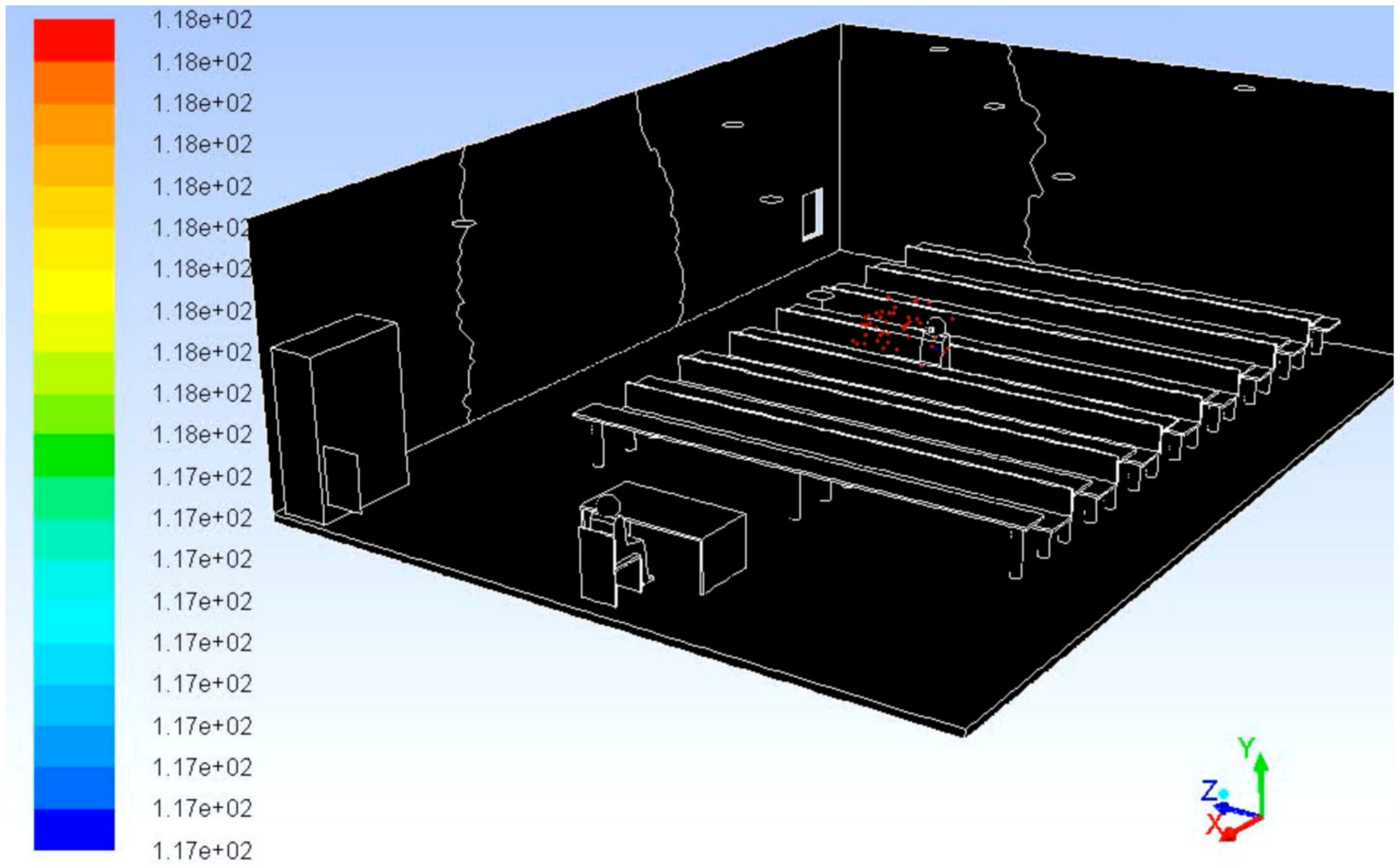

Particle Traces Colored by Particle Residence Time (s) (Time=1.2000e+02)

(c)

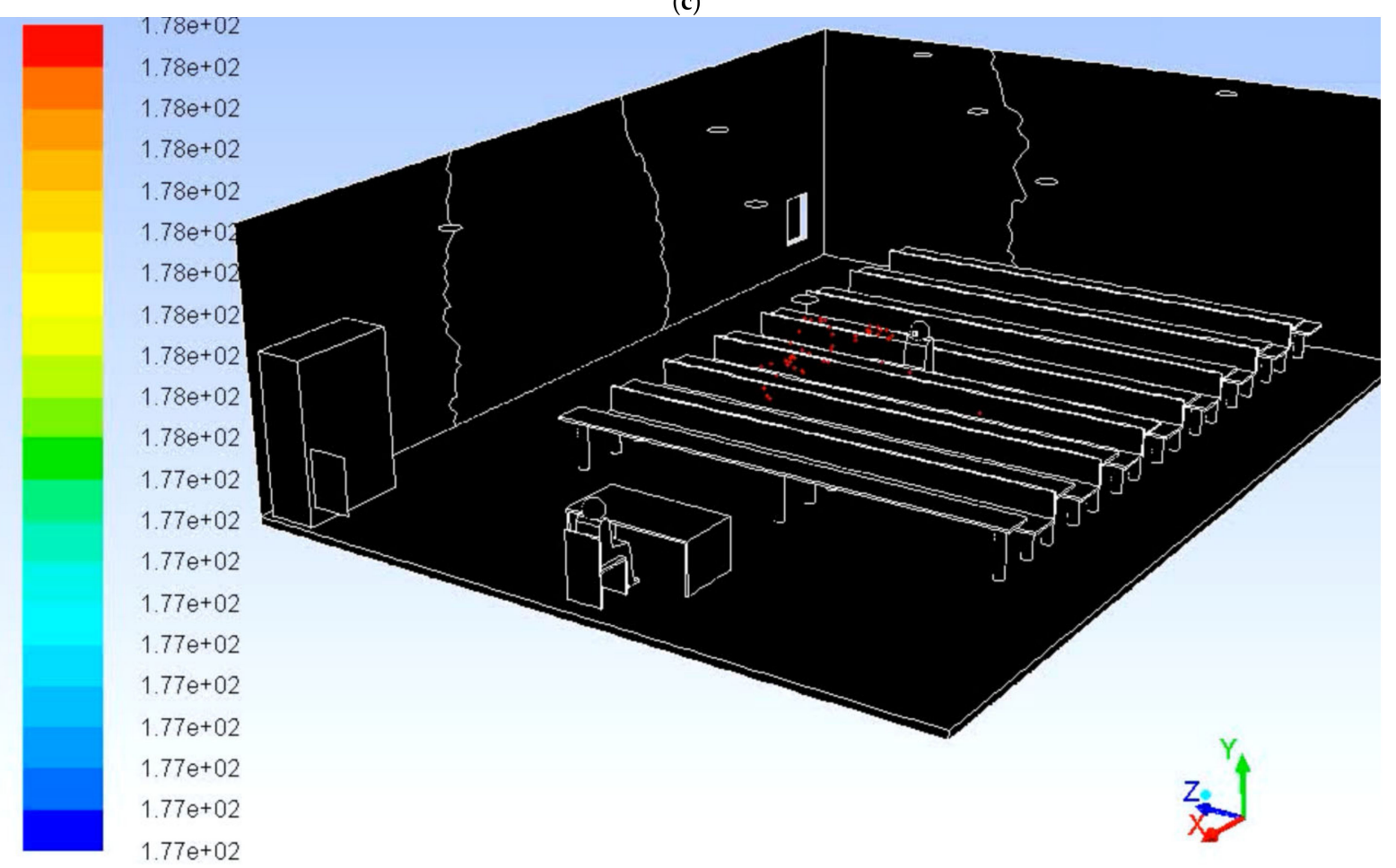

Particle Traces Colored by Particle Residence Time (s) $($ Time $=1.8000 \mathrm{e}+02)$

(d)

Figure 18. Cont. 


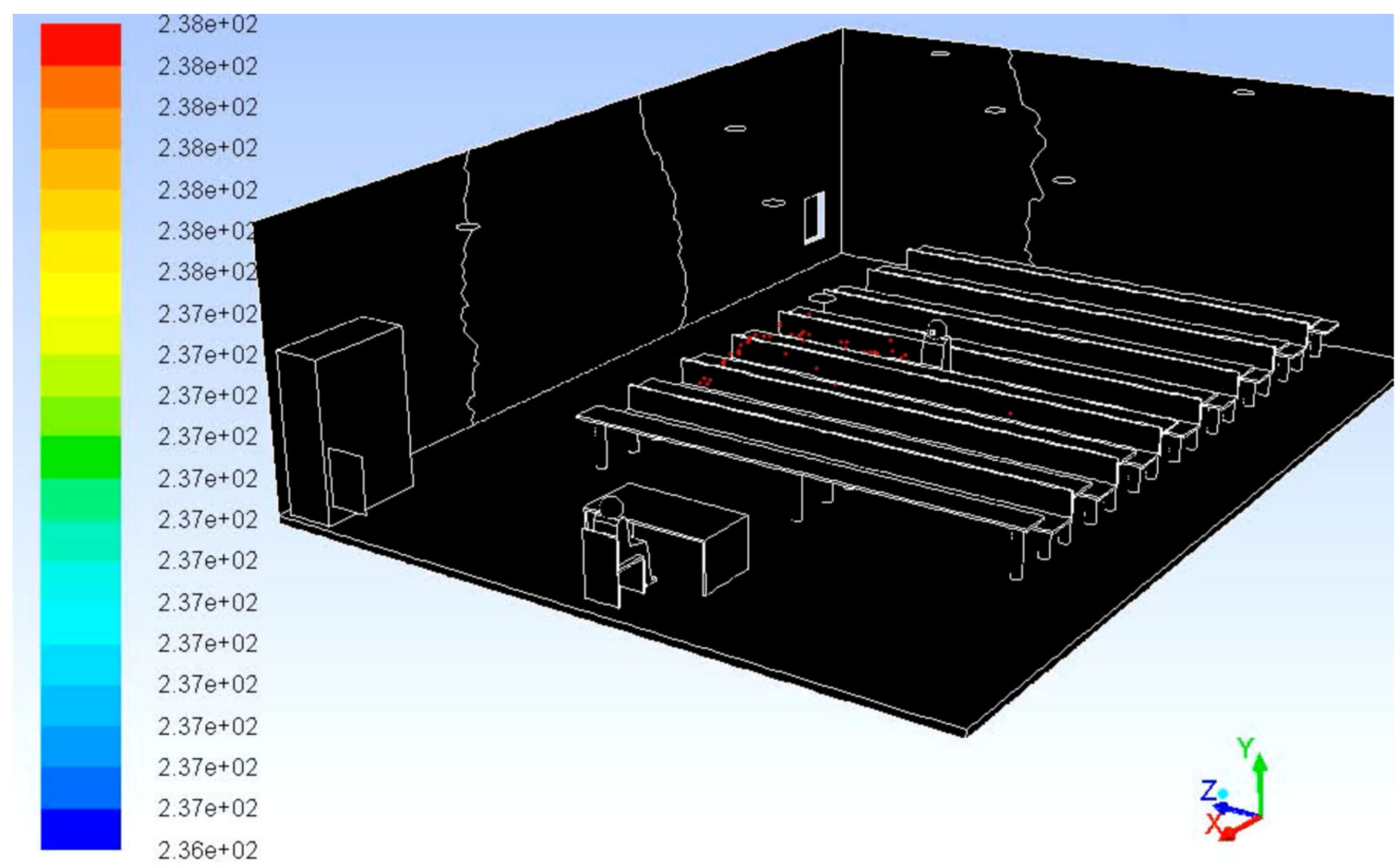

Particle Traces Colored by Particle Residence Time (s) $($ Time $=2.4000 \mathrm{e}+02)$

(e)

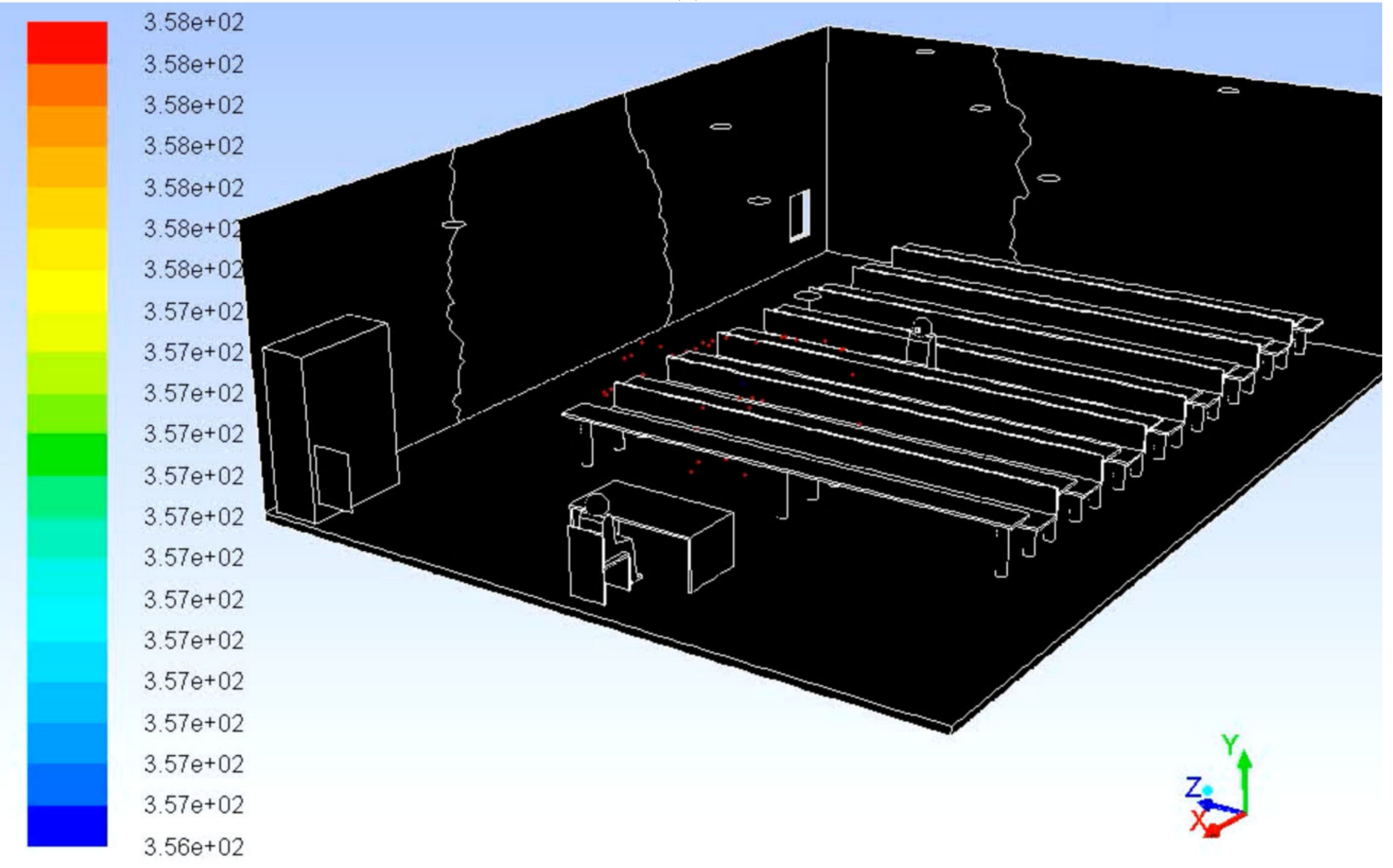

Particle Traces Colored by Particle Residence Time (s) $($ Time $=3.6000 \mathrm{e}+02)$

(f)

Figure 18. Discrete phase modelling of the classroom with open windows: (a) $10 \mathrm{~s}$; (b) $60 \mathrm{~s}$; (c) $120 \mathrm{~s}$; (d) $180 \mathrm{~s}$; (e) $240 \mathrm{~s}$; (f) $360 \mathrm{~s}$. 
The estimations of the $\mathrm{ACH}$ for the selected classroom and office are presented in Figures 19 and 20.

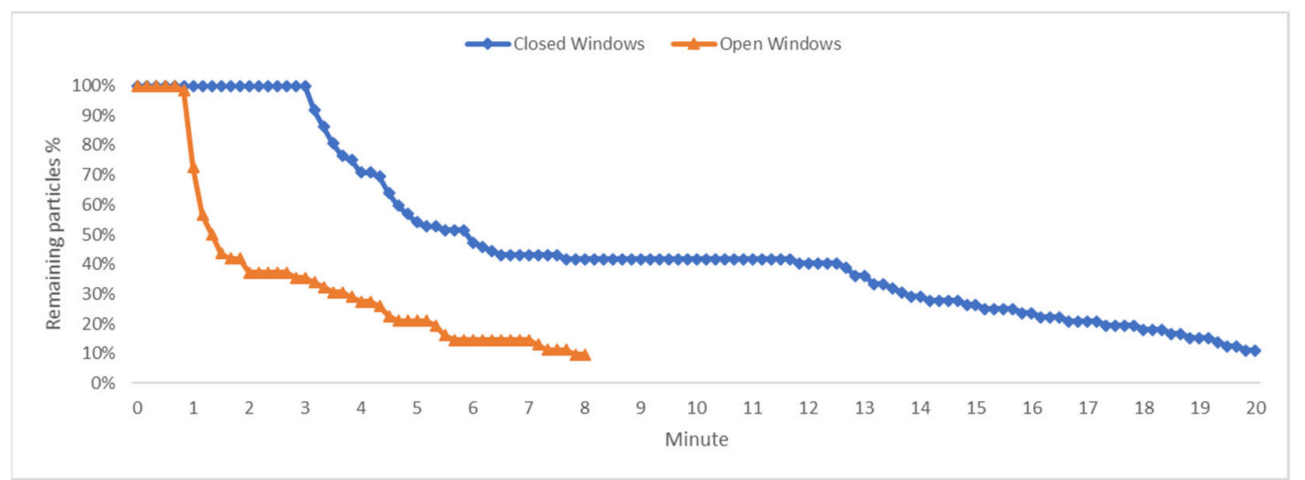

Figure 19. The percentages of the remaining particles in the typical office in two cases of open and closed windows.

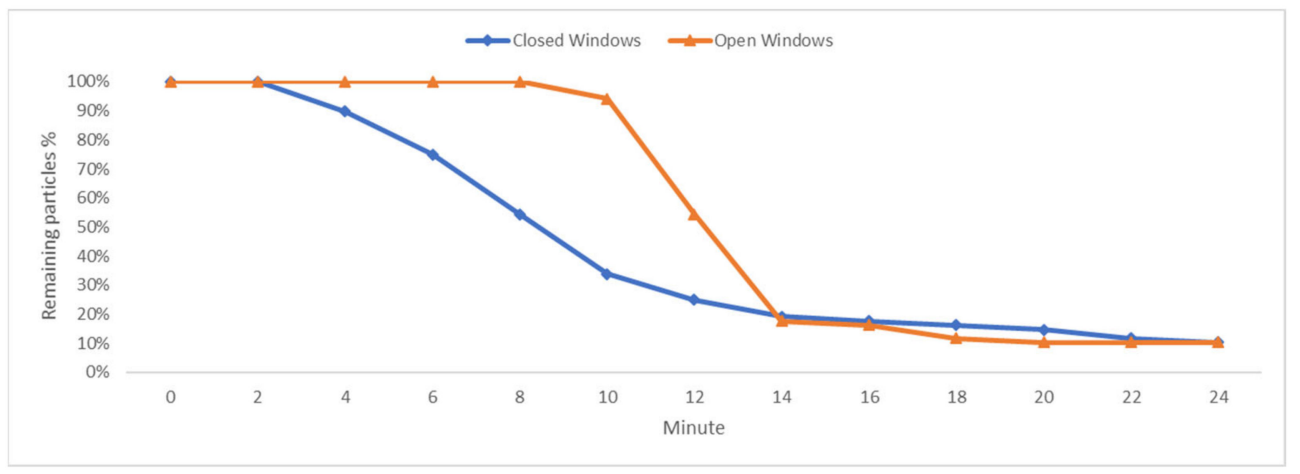

Figure 20. The percentages of the remaining particles in the typical classroom in two cases of open and closed windows.

The ACH in many European countries for residential buildings is currently about 0.35-1 [6], but the recommended ACH for offices is about 2-3, and for classrooms is about 4-6 [85]. Meanwhile, the standard protocol for the prevention of airborne transmission of infections, which could be important during the COVID-19 pandemic, is more than $12 \mathrm{ACH}$ [41].

The theoretical ACH for the case studies with an area of $378 \mathrm{~m}^{3}(12 \mathrm{~m} \times 9 \mathrm{~m} \times 3.5 \mathrm{~m})$, the total size of eight inflows equal to $0.4 \mathrm{~m}^{2}$, the inlet velocity of $1.5 \mathrm{~m} / \mathrm{s}$, and the airflow rate of $0.6 \mathrm{~m}^{3} / \mathrm{s}$ should be $5.6 \mathrm{ACH}$, which is in the range of acceptable IAQ [85]. However, the CFD simulation determined that the full ACH in the office (>95\%) with closed windows was three, nearly half of the theoretical ACH. The ACH value for the same office with open windows was 7.5 (every $8 \mathrm{~min}$ ). By opening windows, the short circuit happened, and this advantage could be used for the proper placement of occupants.

For the classroom, the ACH for both conditions was about 2.5 (every $24 \mathrm{~min}$ ), less than the acceptable IAQ thresholds. The analysis of the ACH in the class reveals the important role of the location of inlets/outlets in addition to the contaminant source location. The contaminant source location was in the center of the class with equal distances from windows and outlets. By opening the windows, the outlet's total size increased while the inlet size remained the same. The new outlets (windows) caused the airflow streamlines divided into four directions, but a decrease in the airflow speed happened. As a result, the time in which the aerosols can exit the class was started with a delay. However, since the outlet number increased, all droplets (>95\%) are evacuated from the class area at the same $24 \mathrm{~min}$. The results show that the full ACH could not increase just by opening windows 
and without considering the airflow path and the locations of tables, objects, and internal walls.

\subsubsection{Recommendations for Future Studies}

The impact of dynamic airflow rate based on the pollutant concentration and the number of occupants is recommended for future studies. Furthermore, the thermal analysis for the same case studies to find a balance between health risk and energy efficiency is recommended for future investigations.

\section{Conclusions}

The airflow analysis results showed the critical impact of windows and the locations of the inlets/outlets of HVAC systems. From the viewpoint of respiratory infection transmission by aerosols, the airflow path is a parameter as important as ACH. The CFD simulation could exhibit optimal placement and safer locations for occupants to decrease the health risk, such as the employee tables in the offices and the placement of students in the classrooms.

The discrete CFD model results determined that the full ACH could be different from theoretical $\mathrm{ACH}$ in the design as the short circuit and dead zones affect the $\mathrm{ACH}$. Moreover, the analysis determined that the dead zones with poor ventilation could be minimized by optimizing the inlets/outlets' locations using CFD simulation. In addition, the role of windows while using the HVAC system can be significant on the ACH and aerosols' trajectory, but both parameters would also depend on the location of the inlets, outlets/windows, and occupants.

The simulation results show that the full $\mathrm{ACH}$ in the office with closed windows was nearly half of the theoretical $\mathrm{ACH}$, and the value of the $\mathrm{ACH}$ for the same office with open windows was more than double compared to that of the closed windows model. However, the $\mathrm{ACH}$ analysis in the classroom shows that, while the full ACH was half of the theoretical ACH, it was nearly the same in both cases of closed and opened windows. As a result, opening windows can decrease the infection risk through two mechanisms, including declining the contamination load through the created short circuit and increasing the airflow paths, that if combined with the optimal placement of the tables, could be more useful. The analysis of supplementary approaches determined that HEPA filters and UV lights could improve the low $\mathrm{ACH}$ and decrease the infection risk in indoor environments.

In conclusion, the impact of windows on $\mathrm{ACH}$ is critical, but the airflow pattern analysis determined the critical role of the HVAC system design. Moreover, in a central HVAC system with full fresh inflow, the ACH in both cases of opened and closed windows could be nearly the same. However, even in the last case, putting windows open would increase the flow paths due to increased outlets. The increase of the airflow paths can decrease the infection risk by contaminated aerosols, as fewer people would be placed in one flow path.

Supplementary Materials: The following are available online at https://www.mdpi.com/article/10 .3390/su13147931/s1, Video S1: Office closed windows., Video S2: Office open windows.

Author Contributions: Conceptualization, B.P.; methodology, B.P. and D.M.; software, B.P. and S.N.N.; validation, B.P. and S.N.N.; formal analysis, B.P., S.A.P. and D.M.; investigation, B.P., S.A.P. and M.T.; data curation, B.P., M.T. and S.N.N.; writing-original draft preparation, B.P., S.A.P. and M.T.; writing-review and editing, B.P., S.A.P. and D.M.; visualization, B.P., S.N.N. and D.M.; supervision, P.P. All authors have read and agreed to the published version of the manuscript.

Funding: This research received no external funding.

Institutional Review Board Statement: Not applicable.

Informed Consent Statement: Not applicable.

Data Availability Statement: Data sharing not applicable. 
Conflicts of Interest: The authors declare no conflict of interest.

\section{References}

1. Liddament, M. A guide to energy efficient ventilation. Phys. Rev. B 1996, 51, 274.

2. Ramalho, O.; Wyart, G.; Mandin, C.; Blondeau, P.; Cabanes, P.A.; Leclerc, N.; Mullot, J.U.; Boulanger, G.; Redaelli, M. Association of carbon dioxide with indoor air pollutants and exceedance of health guideline values. Build. Environ. 2015. [CrossRef]

3. Mandin, C.; Trantallidi, M.; Cattaneo, A.; Canha, N.; Mihucz, V.G.; Szigeti, T.; Mabilia, R.; Perreca, E.; Spinazzè, A.; Fossati, S.; et al. Assessment of indoor air quality in office buildings across Europe-The OFFICAIR study. Sci. Total Environ. 2017. [CrossRef]

4. Arar, S.; Al-Hunaiti, A.; Masad, M.H.; Maragkidou, A.; Wraith, D.; Hussein, T. Elemental contamination in indoor floor dust and its correlation with PAHs, fungi, and gram+/- bacteria. Int. J. Environ. Res. Public Health 2019, 16, 3552. [CrossRef] [PubMed]

5. Hsu, C.N.; Tsai, Y.L. Experimental measurement and computational simulation analysis of indoor air quality in office-integration of voltage adsorption dust collection device and energy recovery ventilator. Sens. Mater. 2020. [CrossRef]

6. Dimitroulopoulou, C. Ventilation in European dwellings: A review. Build. Environ. 2012, 47, 109-125. [CrossRef]

7. Hou, J.; Sun, Y.; Dai, X.; Liu, J.; Shen, X.; Tan, H.; Yin, H.; Huang, K.; Gao, Y.; Lai, D.; et al. Associations of indoor carbon dioxide concentrations, air temperature, and humidity with perceived air quality and sick building syndrome symptoms in Chinese homes. Indoor Air 2021. [CrossRef]

8. Warner, J.A.; Frederick, J.M.; Bryant, T.N.; Weich, C.; Raw, G.J.; Hunter, C.; Stephen, F.R.; McIntyre, D.A.; Warner, J.O. Mechanical ventilation and high-efficiency vacuum cleaning: A combined strategy of mite and mite allergen reduction in the control of mite-sensitive asthma. J. Allergy Clin. Immunol. 2000, 105, 75-82. [CrossRef]

9. Sundell, J. On the Association Between Building Ventilation Characteristics, some Indoor Environmental Exposures, some Allergic Manifestations and Subjective Symptom Reports. Indoor Air 1994, 4, 7-49. [CrossRef]

10. Sun, Y.; Hou, J.; Cheng, R.; Sheng, Y.; Zhang, X.; Sundell, J. Indoor air quality, ventilation and their associations with sick building syndrome in Chinese homes. Energy Build. 2019, 197, 112-119. [CrossRef]

11. Pamonpol, K.; Areerob, T.; Prueksakorn, K. Indoor air quality improvement by simple ventilated practice and sansevieria trifasciata. Atmosphere 2020, 11, 271. [CrossRef]

12. Wallace, L.A.; Emmerich, S.J.; Howard-Reed, C. Continuous measurements of air change rates in an occupied house for 1 year: The effect of temperature, wind, fans, and windows. J. Expo. Anal. Environ. Epidemiol. 2002. [CrossRef]

13. Wargocki, P.; Sundell, J.; Bischof, W.; Brundrett, G.; Fanger, P.O.; Gyntelberg, F.; Hanssen, S.O.; Harrison, P.; Pickering, A.; Seppänen, O.; et al. Ventilation and health in non-industrial indoor environments: Report from a European Multidisciplinary Scientific Consensus Meeting (EUROVEN). Indoor Air 2002, 12, 113-128. [CrossRef] [PubMed]

14. Seppänen, O.A. Association of ventilation rates and $\mathrm{CO} 2$ concentrations with health and other responses in commercial and institutional buildings. Indoor Air 1999, 9, 226-252. [CrossRef]

15. Rosenvald, N. Coronavirus cases. Available online: https://www.worldometers.info/coronavirus/ (accessed on 20 April 2021)

16. Wikipedia Template: COVID-19 Pandemic Data. Available online: https://en.wikipedia.org/wiki/COVID-19_pandemic (accessed on 20 April 2021).

17. Pirouz, B.; Arcuri, N.; Pirouz, B.; Palermo, S.A.; Turco, M.; Maiolo, M. Development of an assessment method for evaluation of sustainable factories. Sustainability 2020, 12, 1841. [CrossRef]

18. Pirouz, B.; Palermo, S.A.; Maiolo, M.; Arcuri, N.; Piro, P. Decreasing water footprint of electricity and heat by extensive green roofs: Case of southern italy. Sustainability 2020, 12, 178. [CrossRef]

19. Turco, M.; Brunetti, G.; Palermo, S.A.; Capano, G.; Grossi, G.; Maiolo, M.; Piro, P. On the environmental benefits of a permeable pavement: Metals potential removal efficiency and Life Cycle Assessment. Urban. Water J. 2020, 1-9. [CrossRef]

20. United Nations The Sustainable Development Goals Report; United Nations Department of Economic and Social Affairs: New York, NY, USA, 2017. [CrossRef]

21. Pirouz, B.; Arcuri, N.; Maiolo, M.; Talarico, V.C.; Piro, P. A new multi-objective dynamic model to close the gaps in sustainable development of industrial sector. In Proceedings of the IOP Conference Series: Earth and Environmental Science, Thessaloniki, Greece, 23-25 October 2019.

22. Palermo, S.A.; Talarico, V.C.; Turco, M. On the LID systems effectiveness for urban stormwater management: Case study in Southern Italy. IOP Conf. Ser. Earth Environ. Sci. 2020, 410. [CrossRef]

23. Mazzeo, D.; Matera, N.; De Luca, P.; Baglivo, C.; Maria Congedo, P.; Oliveti, G. Worldwide geographical mapping and optimization of stand-alone and grid-connected hybrid renewable system techno-economic performance across Köppen-Geiger climates. Appl. Energy 2020. [CrossRef]

24. Mazzeo, D.; Kontoleon, K.J. The role of inclination and orientation of different building roof typologies on indoor and outdoor environment thermal comfort in Italy and Greece. Sustain. Cities Soc. 2020. [CrossRef]

25. Baglivo, C.; Mazzeo, D.; Panico, S.; Bonuso, S.; Matera, N.; Congedo, P.M.; Oliveti, G. Complete greenhouse dynamic simulation tool to assess the crop thermal well-being and energy needs. Appl. Therm. Eng. 2020. [CrossRef]

26. Kameel, R.; El-Din Khalil, E. Thermal comfort vs air quality in air-conditioned healthcare applications. In Proceedings of the 36th AIAA Thermophysics Conference, Orlando, FL, USA, 23-26 June 2003.

27. Pirouz, B.; Maiolo, M. The role of power consumption and type of air conditioner in direct and indirect water consumption. $J$. Sustain. Dev. Energy Water Environ. Syst. 2018. [CrossRef] 
28. Lu, J.; Gu, J.; Gu, J.; Li, K.; Xu, C.; Su, W.; Lai, Z.; Zhou, D.; Yu, C.; Xu, B.; et al. COVID-19 Outbreak Associated with Air Conditioning in Restaurant, Guangzhou, China, 2020. Emerg. Infect. Dis. 2020. [CrossRef]

29. Haghshenas, S.S.; Pirouz, B.; Haghshenas, S.S.; Pirouz, B.; Piro, P.; Na, K.S.; Cho, S.E.; Geem, Z.W. Prioritizing and analyzing the role of climate and urban parameters in the confirmed cases of COVID-19 based on artificial intelligence applications. Int. J. Environ. Res. Public Health 2020, 17, 3730. [CrossRef] [PubMed]

30. Pirouz, B.; Haghshenas, S.S.; Haghshenas, S.S.; Piro, P. Investigating a serious challenge in the sustainable development process: Analysis of confirmed cases of COVID-19 (new type of Coronavirus) through a binary classification using artificial intelligence and regression analysis. Sustainability 2020, 17, 2427. [CrossRef]

31. Pirouz, B.; Nejad, H.J.; Violini, G.; Pirouz, B. The role of artificial intelligence, MLR and statistical analysis in investigations about the correlation of swab tests and stress on health care systems by COVID-19. Information 2020, 11, 454. [CrossRef]

32. Pirouz, B.; Haghshenas, S.S.; Pirouz, B.; Haghshenas, S.S.; Piro, P. Development of an assessment method for investigating the impact of climate and urban parameters in confirmed cases of COVID-19: A new challenge in sustainable development. Int. J. Environ. Res. Public Health 2020, 17, 2801. [CrossRef]

33. Stewart, E.J.; Schoen, L.J.; Mead, K.; Sekhar, C.; Olmsted, R.N.; Vernon, W.; Pantelic, J. ASHRAE Position Document Airborne Infectious Diseases. 2020. Available online: https://www.ashrae.org/file\%20library/about/position\%20documents/pd_ infectiousaerosols_2020.pdf (accessed on 21 April 2021).

34. Fang, Z.; Huang, Z.; Li, X.; Zhang, J.; Lv, W.; Zhuang, L.; Xu, X.; Huang, N. How many infections of COVID-19 there will be in the "Diamond Princess"Predicted by a virus transmission model based on the simulation of crowd flow. arXiv 2020, arXiv:2002.10616.

35. Wiles, K. Cruise Ship AC Systems Could Promote Rapid Coronavirus Spread, Prof Says-Purdue University News. Available online: https:/ / www.purdue.edu/newsroom/releases/2020/Q1/cruise-ship-ac-systems-could-promote-rapid-coronavirusspread,-prof-says.html (accessed on 20 April 2021).

36. Lutz, B.D.; Jin, J.; Rinaldi, M.G.; Wickes, B.L.; Huycke, M.M. Outbreak of invasive Aspergillus infection in surgical patients, associated with a contaminated air-handling system. Clin. Infect. Dis. 2003. [CrossRef]

37. Shajahan, A.; Culp, C.H.; Williamson, B. Effects of indoor environmental parameters related to building heating, ventilation, and air conditioning systems on patients' medical outcomes: A review of scientific research on hospital buildings. Indoor Air 2019, 29, 161-176. [CrossRef] [PubMed]

38. Balaras, C.A.; Dascalaki, E.; Gaglia, A. HVAC and indoor thermal conditions in hospital operating rooms. Energy Build. 2007. [CrossRef]

39. Wong, L.T.; Chan, W.Y.; Mui, K.W.; Lai, A.C.K. An experimental and numerical study on deposition of bioaerosols in a scaled chamber. Aerosol Sci. Technol. 2010. [CrossRef]

40. Olmedo, I.; Nielsen, P.V.; Ruiz de Adana, M.; Jensen, R.L.; Grzelecki, P. Distribution of exhaled contaminants and personal exposure in a room using three different air distribution strategies. Indoor Air 2012. [CrossRef] [PubMed]

41. Beam, E.L.; Schwedhelm, S.; Boulter, K.; Kratochvil, C.; Lowe, J.; Hewlett, A.; Gibbs, S.G.; Smith, P.W. Personal protective equipment processes and rationale for the Nebraska Biocontainment Unit during the 2014 activations for Ebola virus disease. Am. J. Infect. Control. 2016. [CrossRef]

42. Asadi, S.; Bouvier, N.; Wexler, A.S.; Ristenpart, W.D. The coronavirus pandemic and aerosols: Does COVID-19 transmit via expiratory particles? Aerosol Sci. Technol. 2020, 1-4. [CrossRef] [PubMed]

43. Elias, B.; Bar-Yam, Y. Could Air Filtration Reduce COVID-19 Severity and Spread? New Engl. Complex. Syst. Inst. 2020. Available online: https:// necsi.edu/could-air-filtration-reduce-covid19-severity-and-spread (accessed on 22 April 2021).

44. Smith, S.H.; Somsen, G.A.; Van Rijn, C.; Kooij, S.; Van Der Hoek, L.; Bem, R.A.; Bonn, D. Aerosol persistence in relation to possible transmission of SARS-CoV-2. Phys. Fluids 2020. [CrossRef]

45. Van Doremalen, N.; Bushmaker, T.; Morris, D.H.; Holbrook, M.G.; Gamble, A.; Williamson, B.N.; Tamin, A.; Harcourt, J.L.; Thornburg, N.J.; Gerber, S.I.; et al. Aerosol and Surface Stability of SARS-CoV-2 as Compared with SARS-CoV-1. N. Engl. J. Med. 2020. [CrossRef]

46. Santarpia, J.L.; Rivera, D.N.; Herrera, V.L.; Morwitzer, M.J.; Creager, H.M.; Santarpia, G.W.; Crown, K.K.; Brett-Major, D.M.; Schnaubelt, E.R.; Broadhurst, M.J.; et al. Aerosol and surface contamination of SARS-CoV-2 observed in quarantine and isolation care. Sci. Rep. 2020. [CrossRef]

47. Lee, J.; Yoo, D.; Ryu, S.; Ham, S.; Lee, K.; Yeo, M.; Min, K.; Yoon, C. Quantity, size distribution, and characteristics of coughgenerated aerosol produced by patients with an upper respiratory tract infection. Aerosol Air Qual. Res. 2019. [CrossRef]

48. Johnson, G.R.; Morawska, L.; Ristovski, Z.D.; Hargreaves, M.; Mengersen, K.; Chao, C.Y.H.; Wan, M.P.; Li, Y.; Xie, X.; Katoshevski, D.; et al. Modality of human expired aerosol size distributions. J. Aerosol Sci. 2011. [CrossRef]

49. Fernstrom, A.; Goldblatt, M. Aerobiology and Its Role in the Transmission of Infectious Diseases. J. Pathog. 2013. [CrossRef]

50. Kutter, J.S.; Spronken, M.I.; Fraaij, P.L.; Fouchier, R.A.; Herfst, S. Transmission routes of respiratory viruses among humans. Curr. Opin. Virol. 2018, 28, 142-151. [CrossRef] [PubMed]

51. Cole, E.C.; Cook, C.E. Characterization of infectious aerosols in health care facilities: An aid to effective engineering controls and preventive strategies. Am. J. Infect. Control. 1998. [CrossRef]

52. Nicas, M.; Jones, R.M. Relative contributions of four exposure pathways to influenza infection risk. Risk Anal. 2009. [CrossRef] [PubMed] 
53. Shaman, J.; Kohn, M. Absolute humidity modulates influenza survival, transmission, and seasonality. Proc. Natl. Acad. Sci. USA 2009. [CrossRef] [PubMed]

54. Siegel, J.D.; Rhinehart, E.; Jackson, M.; Chiarello, L. Guideline for isolation precautions: Preventing transmission of infectious agents in healthcare settings 2007. In Hospital-Acquired Infections; Nova Science: Hauppauge, NY, USA, 2009 ; ISBN 9781606927281.

55. Sportelli, M.C.; Izzi, M.; Kukushkina, E.A.; Hossain, S.I.; Picca, R.A.; Ditaranto, N.; Cioff, N. Can nanotechnology and materials science help the fight against sars-cov-2? Nanomaterials 2020, 10, 802. [CrossRef]

56. Edmond, M.B.; Wallace, S.E.; McClish, D.K.; Pfaller, M.A.; Jones, R.N.; Wenzel, R.P. Nosocomial bloodstream infections in United States hospitals: A three- year analysis. Clin. Infect. Dis. 1999. [CrossRef]

57. European Standards Standards EN 1822 and EN ISO 29463-EPA, HEPA and ULPA filters-European Standards. Available online: https: / / www.en-standard.eu/set-en-1822-and-en-iso-29463-standards-for-heigh-efficiency-air-filters-epa-hepa-andulpa/ (accessed on 20 April 2021).

58. Abdul Salam, Z.H.; Karlin, R.B.; Ling, M.L.; Yang, K.S. The impact of portable high-efficiency particulate air filters on the incidence of invasive aspergillosis in a large acute tertiary-care hospital. Am. J. Infect. Control. 2010. [CrossRef]

59. Jankowska, E.; Reponen, T.; Willeke, K.; Grinshpun, S.A.; Choi, K.J. Collection of fungal spores on air filters and spore reentrainment from filters into air. J. Aerosol Sci. 2000. [CrossRef]

60. Beggs, C.B.; Donnelly, J.K.; Kerr, K.G.; Sleigh, P.A.; Mara, D.D.; Cairns, G. The use of engineering controls to disinfect Mycobacterium tuberculosis and airborne pathogens in hospital buildings. Indoor Built Environ. 2000. [CrossRef]

61. Chuaybamroong, P.; Chotigawin, R.; Supothina, S.; Sribenjalux, P.; Larpkiattaworn, S.; Wu, C.Y. Efficacy of photocatalytic HEPA filter on microorganism removal. Indoor Air 2010. [CrossRef]

62. Sportelli, M.C.; Picca, R.A.; Cioffi, N. Recent advances in the synthesis and characterization of nano-antimicrobials. TrAC Trends Anal. Chem. 2016, 84, 131-138. [CrossRef]

63. Ungur, G.; Hrůza, J. Modified polyurethane nanofibers as antibacterial filters for air and water purification. RSC Adv. 2017. [CrossRef]

64. Grant, W.B.; Giovannucci, E. The possible roles of solar ultraviolet-B radiation and vitamin D in reducing case-fatality rates from the 1918-1919 influenza pandemic in the United States. Dermatoendocrinol 2009, 10, 9063. [CrossRef]

65. Bang, J.I.; Park, J.; Choi, A.; Jeong, J.W.; Kim, J.Y.; Sung, M. Evaluation of UR-UVGI system for sterilization effect on microorganism contamination in negative pressure isolation ward. Sustainability 2018, 10, 3192. [CrossRef]

66. KLARAN What Is UVC Light? Available online: https://www.klaran.com/klaran-university/about-uvc (accessed on 21 April 2021).

67. Sehulster, L.; Chinn, R.Y.W. Guidelines for environmental infection control in health-care facilities. Recommendations of CDC and the Healthcare Infection Control Practices Advisory Committee (HICPAC). MMWR Recomm. Rep. 2003, 52, 1-42.

68. Sehulster, L.; Chinn, R.Y.W. Guidelines for environmental infection control in health-care facilities. Morb. Mortal. Wkly. Rep. 2003, $52,1-42$.

69. Kowalski, W. Ultraviolet Germicidal Irradiation Handbook: UVGI for Air and Surface Disinfection; Springer: Cham, Switzerland, 2009; ISBN 9783642019982.

70. Talbot, E.A.; Jensen, P.; Moffat, H.J.; Wells, C.D. Occupational risk from ultraviolet germicidal irradiation (UVGI) lamps. Int. J. Tuberc. Lung Dis. 2002, 6, 738-741. [PubMed]

71. Nicas, M.; Miller, S.L. A multi-zone model evaluation of the efficacy of upper-room air ultraviolet germicidal irradiation. Appl. Occup. Environ. Hyg. 1999. [CrossRef]

72. IUVA COVID-19 FAQ, What is the UVC dose for killing or disabling the COVID-19 virus? 2020. Available online: https: / /iuva.org/iuva-covid-19-faq (accessed on 21 April 2021).

73. AHRI COVID Transmission and Air Conditioning Facts. Available online: http://www.ahrinet.org/App_Content/ahri/files/ NewsRoom/AHRI-COVID-Report-FAQ.pdf (accessed on 21 April 2021).

74. Xu, H.; Yan, C.; Fu, Q.; Xiao, K.; Yu, Y.; Han, D.; Wang, W.; Cheng, J. Possible environmental effects on the spread of COVID-19 in China. Sci. Total Environ. 2020. [CrossRef]

75. Lim, T.; Cho, J.; Kim, B.S. The influence of ward ventilation on hospital cross infection by varying the location of supply and exhaust air diffuser using CFD. J. Asian Arch. Build. Eng. 2010. [CrossRef]

76. Holland, M.; Zaloga, D.J.; Friderici, C.S. COVID-19 Personal Protective Equipment (PPE) for the emergency physician. Vis. J. Emerg. Med. 2020. [CrossRef] [PubMed]

77. Palermo, S.A.; Zischg, J.; Sitzenfrei, R.; Rauch, W.; Piro, P. Parameter Sensitivity of a Microscale Hydrodynamic Model. In Proceedings of the Green Energy and Technology; Springer International Publishing: Basel, Switzerland, 2019.

78. Piro, P.; Carbone, M.; Garofalo, G.; Sansalone, J. CSO treatment strategy based on constituent index relationships in a highly urbanised catchment. Water Sci. Technol. 2007, 56, 85-91. [CrossRef]

79. Piro, P.; Carbone, M.; Sansalone, J. Delivery and Frequency Distributions of Combined Wastewater Collection System Wet and Dry Weather Loads. Water Environ. Res. 2012. [CrossRef]

80. Carbone, M.; Garofalo, G.; Nigro, G.; Piro, P. A conceptual model for predicting hydraulic behaviour of a green roof. Procedia Eng. 2014, 70, 266-274. [CrossRef]

81. Popovici, C.G. HVAC System Functionality Simulation Using ANSYS-Fluent. Energy Procedia 2017, 112, 360-365. [CrossRef] 
82. ANSYS Chapter 1: Basic Fluid Flow. Available online: https://ansyshelp.ansys.com/account/secured?returnurl=/Views/ Secured/corp/v202/en/flu_th/flu_th_chp_models.html (accessed on 21 April 2021).

83. ANSYS Inc. ANSYS FLUENT User's Guide, chapter 15. Discrete Phase. Available online: https://www.afs.enea.it/project/ neptunius/docs/fluent/html/th/node238.htm (accessed on 21 April 2021).

84. Yongson, O.; Badruddin, I.A.; Zainal, Z.A.; Aswatha Narayana, P.A. Airflow analysis in an air conditioning room. Build. Environ. 2007. [CrossRef]

85. ANSI ANSI/ASHRAE Standard 62.1-2010; Ventilation for Acceptable Indoor Air Quality. Ashrae. 2007. Available online: http:/ /arco-hvac.ir/wp-content/uploads/2016/04/ASHRAE-62_1-2010.pdf (accessed on 22 April 2021).

86. Asmi, A.; Putra, J.C.P.; Rahman, I.A. Simulation of room airflow using comsol multiphysics software. Appl. Mech. Mater. 2013, 465-466, 571-577. [CrossRef]

87. Fulpagare, Y.; Agrawal, N. Experimental Investigation on Room Ait Flow Pattern \& Thermal Comfort Qantification. Int. J. Eng. Sci. Emerg. Technol. IJESET 2013, 6, 120-132.

88. Yu, J.; Leng, K.; Wang, F.; Ye, H.; Luo, Y. Simulation study on dynamic thermal performance of a new ventilated roof with form-stable pcm in Southern China. Sustainability 2020, 12, 9315. [CrossRef]

89. Yang, X.; Ou, C.; Yang, H.; Liu, L.; Song, T.; Kang, M.; Lin, H.; Hang, J. Transmission of pathogen-laden expiratory droplets in a coach bus. J. Hazard. Mater. 2020. [CrossRef] [PubMed]

90. Yang, L.; Li, X.; Yan, Y.; Tu, J. Effects of cough-jet on airflow and contaminant transport in an airliner cabin section. J. Comput. Multiph. Flows 2018. [CrossRef]

91. Yan, Y.; Li, X.; Yang, L.; Yan, P.; Tu, J. Evaluation of cough-jet effects on the transport characteristics of respiratory-induced contaminants in airline passengers' local environments. Build. Environ. 2020. [CrossRef]

92. Zhang, B.; Guo, G.; Zhu, C.; Ji, Z. Transport of aerosol by coughing in an air-conditioned space. In Proceedings of the Thermal and Fluids Engineering Summer Conference, Las Vegas, NV, USA, 14-17 April 2019.

93. Talaat, K.; Abuhegazy, M.; Mahfoze, O.A.; Anderoglu, O.; Poroseva, S.V. Simulation of aerosol transmission on a Boeing 737 airplane with intervention measures for COVID-19 mitigation. Phys. Fluids 2021, 33, 33312. [CrossRef]

94. Wang, J.X.; Cao, X.; Chen, Y.P. An air distribution optimization of hospital wards for minimizing cross-infection. J. Clean. Prod. 2021, 279. [CrossRef]

95. Zhang, C.; Bounds, C.P.; Foster, L.; Uddin, M. Turbulence modeling effects on the CFD predictions of flow over a detailed full-scale sedan vehicle. Fluids 2019, 4, 148. [CrossRef]

96. Dong, H.; Qin, Z.; Liu, S.; Li, Y.; Shen, Y.; Wang, H.; Zong, Y.; Wu, X.; Si, H. Numerical investigation into the air flow distributions of the air conditioning system in the modular data center. Adv. Appl. Math. Mech. 2019, 11,91-107. [CrossRef]

97. Ahn, J.; Choi, H.Y. Effects of Supply Angle on Thermal Environment of Residential Space with Hybrid Desiccant Cooling System for Multi-Room Control. Appl. Sci. 2020, 10, 7271. [CrossRef]

98. $\mathrm{Ng}$, K.C.; Kadirgama, K.; Ng, E.Y.K. Response surface models for CFD predictions of air diffusion performance index in a displacement ventilated office. Energy Build. 2008, 40, 774-781. [CrossRef]

99. Zhu, S.; Dalgo, D.; Srebric, J.; Kato, S. Cooling efficiency of a spot-type personalized air-conditioner. Build. Environ. 2017, 121, 35-48. [CrossRef]

100. Pirouz, B.; Mazzeo, D.; Palermo, S.A.; Naghib, S.N.; Turco, M.; Piro, P. CFD Investigation of Vehicle's Ventilation Systems and Analysis of ACH in Typical Airplanes, Cars, and Buses. Sustainability 2021, 13, 6799. [CrossRef]

101. Yan, Y.; Li, X.; Shang, Y.; Tu, J. Evaluation of airborne disease infection risks in an airliner cabin using the Lagrangian-based Wells-Riley approach. Build. Environ. 2017, 121, 79-92. [CrossRef] [PubMed]

102. Abuhegazy, M.; Talaat, K.; Anderoglu, O.; Poroseva, S.V.; Talaat, K. Numerical investigation of aerosol transport in a classroom with relevance to COVID-19. Phys. Fluids 2020, 32. [CrossRef] [PubMed] 